\title{
Firm ownership, quality of government and innovation: Evidence from patenting in the telecommunication industry
}

\author{
Stefano Clò ${ }^{\mathrm{a}}$, Massimo Florio ${ }^{\mathrm{b}}$, Francesco Rentocchini ${ }^{\mathrm{b}, *}$ \\ ${ }^{a}$ University of Florence, Italy \\ ${ }^{\mathrm{b}}$ Department of Economics, Management and Quantitative Methods, University of Milan, Italy
}

\section{A B S T R A C T}

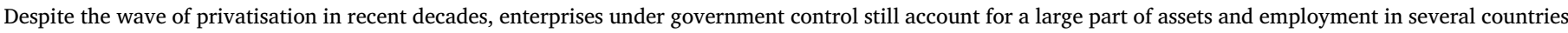

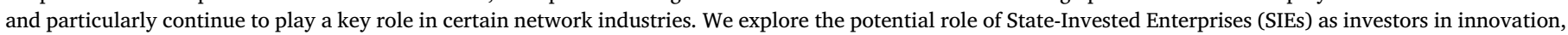

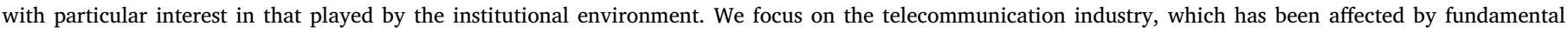

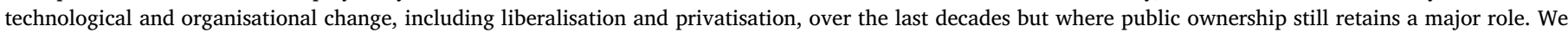

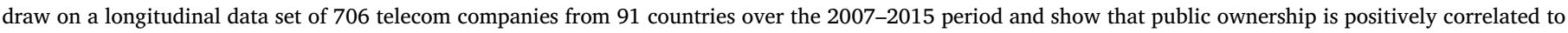

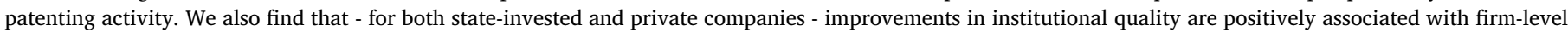

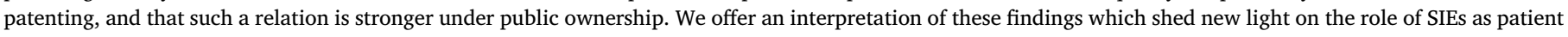
investors.

\section{Introduction}

The role of innovation in modern growth theory has been firmly established since the contribution by Arrow (1962) who identified learning and R\&D as an endogenous driver of change. Subsequent developments of this theory (e.g. Romer, 1986, 1990; Aghion and Howett, 1992; Nelson, 2005) established a potential role for government support for R\&D when firms are unable to attain the optimal quantity of investment in knowledge creation. R\&D by firms is constrained by two market failures: the uncertainty of returns to R\&D (Foray, 2004) and externalities due to knowledge spillovers (Griliches, 1979, Grossman and Helpman, 1991). A traditional view to counteract any externality consists in government intervention in different forms. Examples of government interventions to support R\&D include subsidies to private firms (Busom, 2000; Salter and Martin, 2001; Trajtenberg, 2002), collaboration between public universities and firms (Bergman, 1990; Mansfield, 1991, 1998; Veugelers and Cassiman, 2005; Segarra-Blasco and ArauzoCarod, 2008), public procurement for innovation by Big Science (Castelnovo et al., 2018; Florio et al., 2018), and combined demand and supply-side policies (Wonglimpiyarat, 2006; Guerzoni and Raiteri, 2015). More recently Mazzucato $(2013,2016)$ has promoted the view that the government's role goes beyond the correction of market failures as it supports technological breakthrough, which in turn creates entirely new markets. Mazzucato $(2017,2018)$ advocates a governmental mission-oriented innovation policy to address big societal challenges.

In this paper, we explore another mechanism of government support for innovation: the potential role of enterprises under public control as active players in technological creation. We focus on the telecommunication industry, which has been affected by fundamental technological and organisational change, including liberalisation and privatisation, over the last decades but where the public ownership of major players is still important.

Existing evidence on the relation between firms' ownership and innovation outcome at firm level is far from being conclusive (Sterlacchini, 2012; Belloc, 2014; Fang et al., 2016; Rong et al., 2017; Demircioglu and Audretsch, 2017). A strand of literature points to the inferior innovation capability of enterprises under public control due to their internal governance structure, lack of adequate monitoring and market incentives and risk of political capture. On the other side, one may argue that public enterprises might have a better attitude towards innovation. In fact, both ownership concentration and stability, and the departure from short-term goals may reduce the risk-aversion associated with an activity which exchanges current and certain returns for future and uncertain ones.

The relevance of this issue is motivated by evidence that, despite the wave of privatisation that affected the world economy in recent decades, enterprises under government control still account for a large part of assets and employment in both developed and developing economies, and continue to play a central role in network industries (e.g.

\footnotetext{
* Corresponding author.

E-mail addresses: stefano.clo@unifi.it (S. Clò), massimo.florio@unimi.it (M. Florio), francesco.rentocchini@unimi.it, f.rentocchini@soton.ac.uk (F. Rentocchini).
} 
telecommunication, oil \& gas, railway, power generation). ${ }^{1}$ Moreover, although there is consistent evidence on public ownership under-performance compared to private companies in terms of efficiency, productivity and profitability (e.g. Shleifer and Vishny, 1994, Megginson and Netter, 2001, Dewenter and Malatesta, 2001), major market-oriented reforms have increasingly exposed them to a new set of incentives. Markets have been widely liberalised and former public monopolists have been brought to compete against private enterprises (Khandelwal et al., 2013; Koske et al., 2015). Traditional State-owned enterprises have undergone major governance reforms as well. Their proprietary structure has faced radical changes: many governments have partially divested from them and, while continuing to maintain the residual right to appoint the relative majority of the board, have opened their shareholding structure to private equity (Bortolotti and Faccio, 2009). In light of these transformations, enterprises under public control are increasingly referred to as State-invested enterprises (SIEs) (Christiansen and Kim, 2014). ${ }^{2}$ Various SIEs have been listed on a stock exchange where they currently compete with private enterprises in the collection of financial resources (Pargendler et al., 2013). The consequence of these reforms has been a deep transformation in their internal governance and management organisation, resulting in an improvement in their financial accountability and economic performance (Musacchio and Lazzarini, 2018). Thus, the question of whether contemporary SIEs differ from their private competitors in terms of their technological capabilities arises. This is our first research question.

This paper further contributes to the existing literature by investigating the issue of ownership and innovation through the lens of institutional economic theory (Williamson, 1985; North, 1990). Our second research question is whether SIEs' innovation-oriented attitude, compared to private companies, is likely to be differentially affected by the quality of government and of institutions in general. Indeed, governments can appoint the SIEs' managers, thus directing them on the objectives to achieve, and are likely to influence SIEs' internal governance, monitoring and incentives mechanisms, and ultimately its innovation capability. Consequently, we contend that the relationship between firm-level innovation and ownership nature varies depending on institutional quality. Our approach is motivated by the recognition that the efficiency of the firm - and its ability to innovate - crucially depends on institutional quality (Sala-i-Martin, 2002; Tebaldi and Elmslie, 2013). We argue that this relation is stronger under public ownership because, in this case, institutions affect both the quality of the external environment where firms perform their economic activity and the quality of SIEs' internal governance and management mechanisms.

In the present paper, we address these issues by analysing a comprehensive dataset comprising information on companies operating all around the globe in the telecommunication industry. To the best of our knowledge, no studies have focused on the relation between ownership and innovation for: (i) a sector (i.e. telecommunication) involving firms that have undergone major transformations in their ownership nature and competitive environment; (ii) companies operating in widely different geographical areas, thus entailing a large variance in the quality

\footnotetext{
${ }^{1}$ For a review see PWC (2015), Christiansen and Kim (2014), European Commission (2016). According to the OECD, in the telecom sector, the major market player is still controlled by the government (by means of a majority or minority of shares) in the following countries: Austria, Belgium, France, Germany, Japan, Luxembourg, Norway, Slovak Republic, Slovenia, Sweden, Switzerland, Turkey, China, India, South Africa, Cyprus, Latvia and Romania (Koske et al., 2015).

${ }^{2}$ In this paper, we prefer to adopt the term "state-invested enterprises" to take into account the important changes these firms have undergone in recent years (i.e. government divestment, entrance of private equity, etc.). We use the traditional term "state-owned enterprise" only when we use arguments that explicitly refer to a period of time before these major changes took place.
}

of the institutions of the home country.

We considered patents as an empirical proxy of innovation by firms and we modelled the interaction between ownership and institutional quality as our variables of interest after controlling for firm-level, time and geographical characteristics. Our investigation relied on three data sources: information from the ORBIS dataset on economic characteristics and ownership structure at the firm-level; detailed patent-level information from PATSTAT; World Bank's Worldwide Governance Indicators (WGI) database for data on countries' institutional quality. Our final sample comprises 706 telecom companies from 91 countries over the 2007-15 period, for a total of 4854 firm-year observations.

Our main finding is that, firstly, government ownership per se positively correlates to patenting activity. Secondly, while improvements in institutional quality are positively associated with firm-level patenting in general, such a relation is stronger under public ownership. In fact, in countries with high-quality government and institutions, SIEs show better patenting performance than private firms, while the reverse occurs in countries with a low-institutional profile. We interpret this main result in the following way: SIEs are more effective in terms of patenting output when they benefit from improved internal governance mechanisms and when they depart from the short-term profit goal of private enterprises. This is true, however, only in countries with highlevel institutions. When corruption is at a minimum level, accountable governments are likely to adopt transparent selection procedures and effective monitoring mechanisms and commit the SIE's management on long-term goals. This view can be consistent with two main arguments. The first relates to short-termism argument and the risky nature of the R\&D activity which implies uncertain and time-deferred returns (Porter, 1992; Stein, 1988). When facing pressure for immediate results, managers of private (privatised) firms are more likely to have a risk-averse attitude and to redirect financial resources from risky patenting activities to more conventional and short-term oriented activities. The second argument relates to the possibility of the patenting activity to generate potential spillovers and positive externalities (such as those related to connectivity and the digital agenda) that are more likely to be internalised by SIEs rather than by private firms. Conversely, in countries with corruption problems, the SIEs' controlling governments are likely to give priority to the short-term private interests of politicians and other stakeholders and do not implement sound management strategies, thus causing resources misallocation and bringing the SIEs to underperform compared to private peers in terms of technological development. ${ }^{3}$

The paper is structured as follows. Section 2 provides a brief review of the core contributions addressing the relationship between public versus private ownership structure and firm performance, with a focus on innovation activity. The section concludes by formulating a set of research questions pertaining to the effect of ownership structure, type of control and institutional quality on innovation activity at the firm level. Section 3 presents the dataset and describes the sample, variables and method that were employed for the present empirical analysis. Section 4 presents the results of the econometric analysis and robustness checks. Section 5 summarises the main findings and discusses the most relevant implications of our study.

\section{Literature review and research questions}

Ownership of the firm is increasingly recognised as a factor that affects its capacity to develop technological innovation (Choi et al., 2011, 2012; Lazzarini et al., 2016). Indeed, the firm's internal

\footnotetext{
${ }^{3}$ Following the suggestion by a reviewer, we acknowledge that strategic patenting behaviour (e.g. the creation of patent thickets) can be aimed at fending off competition. In this case, more patents would have the opposite effect than serving valuable social goals. This is an issue that goes beyond the scope of our work but that deserves attention from future research.
} 
organisation, governance mechanisms, and the goals that managers are instructed to achieve crucially depend on the nature of the owner retaining residual rights of control over the firm. Building on the career concern hypothesis formulated by Holmstrom (1999), Aghion et al. (2013) find that, among listed companies, those in which institutional owners participate (hedge and mutual funds) are associated with more innovation. The authors argue that managers may be reluctant to undertake R\&D investments with an intrinsic probability of failure, especially when the principal does not develop the monitoring mechanisms that are required to understand whether a potential failure of the project is due to the manager's incompetence or other reasons. To contrast this risk, by implementing effective monitoring and incentive mechanisms, institutional owners lower information asymmetries and reduce managers' career risk in association with projects with uncertain returns. This encourages an increase in managers' attitude towards innovative projects.

Other studies have investigated this issue, finding different and potentially conflicting channels through which the ownership nature of the firm affects its capacity to innovate (Belloc, 2014). An established stream of literature points to the lower efficiency of traditional public ownership compared to private companies (Vining and Boardman, 1992; Shleifer, 1998). Following this line of argument, the main source of their inefficiency is traced back to the government's inability to (i) effectively monitor managers' behaviour and to (ii) design an adequate set of incentives aimed at reducing principal-agent problems by aligning owners' and managers' objectives (Holmstrom and Milgrom, 1991; Laffont and Tirole, 1993). Other reasons behind public ownership inferior efficiency refer to the lack of hard budget constraints and the absence of a takeover threat (Vickers and Yarrow, 1991; La Porta et al., 1998), as low replacement risk fails to give public managers the adequate incentives to run the firm efficiently and improve its performance. A final important source of inefficiency is the risk of political interference and capture by private interests (Shleifer and Vishny, 1994; Mauro, 1995). Bad governments may use their controlled enterprises as a vehicle to pursue private goals at the expenses of social well-being, causing the misallocation of resources. By hindering efficiency and productivity, these constraints are likely to negatively affect the traditional state-owned enterprises' dynamic efficiency and capability to develop successful innovations. This argument is confirmed by recent evidence from China on the inferior innovative performance of state-owned enterprises compared to private firms (Hu and Jefferson, 2009; Boeing et al., 2016; Fang et al., 2016). Notably, Rong et al. (2017) find that the positive impact of institutional ownership on innovation (Aghion et al., 2013) is not significant when institutional owners hold a minority of stakes in firms that are controlled by the State where managers are likely to be appointed according to their political connections rather than their business competences.

Contrary to this dominant view, there is evidence suggesting that enterprises under public control can actually perform similarly to private enterprises (Szarzec and Nowara, 2017) or even better in some sectors and countries (Borghi et al., 2016; Florio, 2013); in some circumstances they exhibit certain internal features that may provide a comparative innovation advantage with respect to private companies. A first argument relates to the risk of short-termism that may affect profitmaximizing private enterprises. It has been argued that pressure for immediate results induces managers to redirect financial resources from R\&D activities to more conventional and short-term oriented activities (Porter, 1992; Stein, 1988). Evidence of short-termism has been found when looking at private enterprises listed on the stock market (Ferreira et al., 2013), especially when they are participated by speculating investors (Bushee 1998, 2001), and when enterprises are acquired through excessive means of financial leverage. On top of this argument, the traditional public economics literature stresses the difference in the objective functions between private and public enterprises that allow the latter to adopt strategies and investments with long-term returns that private investors looking for high and fast returns are not willing to undertake. When activities entail positive externalities that cannot be fully monetised, private enterprises might be reluctant to undertake optimal investments, while this market failure is less likely to occur under public owership (Atkinson and Stiglitz, 1980; Kaldor, 1980).

Another relevant issue for the firm's capacity to innovate is its internal stability. Ownership concentration is found to be positively associated with R\&D expenditures and innovation (Francis and Smith, 1995). The propensity and capacity to develop long-term R\&D projects is likely to benefit from a stable environment. Conversely, managers under a continuous threat of replacement may increase their preference of conventional projects with a lower probability of failure (Stein, 1988; Kaplan et al., 2012; Sapra et al., 2013).

The departure from short-term profits, features of internal long-term stability and ownership concentration are likely to characterise firms under government control and may put public managers in a better position to deal with long-term innovative projects characterised by uncertain and time-deferred returns. These arguments are supported by the empirical evidence that privatisation has been associated with a decline in R\&D activity (Munari and Oriani, 2005; Sterlacchini, 2012; Xie, 2012), and that privatisation through leveraged buyout has reduced R\&D intensity and investments in innovation (Zahra and Fescina, 1991; Long and Ravenscraft's, 1993).

Other insights on this issue have been derived by the theoretical literature on mixed oligopoly, which represents the market structure for the majority of telecommunication companies in many countries and in a global perspective. State-owned enterprises, state-invested or partially privatised corporations, and private companies, are all (potentially) strategically interacting among them, often to secure larger market shares. Earlier theoretical literature on mixed oligopolies has tried to model the innovation and R\&D implications of such setting with an early example being Delbono and Denicolò (1993) (for more recent contributions see Gil-Moltò et al., 2011,2019). The authors focus on the optimal R\&D subsidies in a mixed duopoly market and show that privatisation of a state-owned enterprise reduces R\&D activity and social welfare in the duopoly market, even when R\&D subsidies are provided. Overall the mixed oligopoly strand of literature supports the view that R\&D expenditures are higher in SIEs because of differences in their objectives in comparison to profit maximising private firms. ${ }^{4}$

Following the discussion above, earlier literature has found contrasting results, thus preventing the development of any unambiguous prediction on the impact of ownership on innovation. We believe that these apparently conflicting views are due to an important omission in the analysis and can be reconciled within a broader general conceptual framework once the role of institutions is properly taken into consideration. Notably, we argue that institutions are linked to the ownership of the firm by a double relation. One is external to the firm itself and affects both private and public enterprises, the other is internal to the firm and mainly involves enterprises under governmental control.

Institutions govern economic and social interactions within a country and can be defined as the broad set of formal and informal rules shaping the environment where citizens interact in society and where firms carry out their economic activity (North, 1990). It is widely recognised that the quality of institutions affects firms' strategies, performance and, ultimately, economic growth (Mauro, 1995; Rajan and Zingales, 1998; Acemoglu et al., 2001; Helpman, 2004; Rigobon and Rodrik, 2004). The certainty of the rule of law ${ }^{5}$; the strengths and

\footnotetext{
${ }^{4}$ Extending these models in a game theoretic setting with multiple players, different ownership and regulatory regime is beyond the scope of the current work. Nevertheless, we see as an interesting future avenue of research given the features of the contemporary global telecommunication industry.

${ }^{5}$ The rule of law has been defined as a principle of governance in which "all persons, institutions and entities, public and private, including the State itself, are accountable to laws that are publicly promulgated, equally enforced and
} 
effectiveness of law enforcement, judicial and correctional procedures; the degree of government effectiveness, transparency and accountability; the absence of corruption: all these elements contribute to determining the quality of institutions within a country. They constrain the firms' endowment of resources, affect their production costs and consequently shape their strategies and decision-making processes. Previous research shows that the linkage between institutional quality and firms' performance (Baumol, 1990; Dollar et al., 2005; Commander and Svejnar, 2011) positively affects the process of knowledge accumulation (Sala-i-Martin, 2002; Gradstein, 2004; Rodriguez-Pose and Di Cataldo, 2015). Boschma and Capone (2015) find that institutions affect the direction of the diversification process and their industrial evolution. Tebaldi and Elmslie (2008, 2013) provide empirical evidence that the absence of corruption, the protection of property rights and the effectiveness of judiciary systems impact on the economy's rate of innovation and are significant in explaining crosscountry patenting variations.

Building on this extensive literature, we firstly argue that the positive relation between institutions and firm dynamic efficiency is external to the firm itself and does not depend on their ownership nature. Both public and private firms benefit from a safe environment and their propensity towards innovative but risky investments increases with their confidence in the quality of the underlying institutional framework. However, we also argue that there is a second channel linking institutions and enterprises. As opposed to the previous one, this relation is internal to the firm and is more relevant for SIEs than for private enterprises. The quality of the government (e.g. transparency, accountability, absence of corruption) is likely to affect public management appointment procedures, SIEs' internal governance and monitoring mechanisms, and the objectives that SIEs are instructed to achieve.

The phenomena of political capture, orientation towards immediate personal objectives, and misallocation of resources are more likely to take place in countries characterised by low quality institutions. Enterprises under the control of a malevolent government are brought to bargain short-term private returns at the expense of long-term social goals. Thus, we expected that a bad institutional quality is detrimental to SIEs' innovation performance compared to private enterprises. Conversely, SIEs that are located in countries with high quality institutions are more likely to rely on internal stability, transparent monitoring and selection procedures and clear commitment towards long term socially valuable goals. Therefore, we expected high institutional quality to have an incremental positive effect on SIEs' capacity to innovate compared to private enterprises.

In light of these considerations, our empirical analysis explicitly considered both external and internal dimensions linking institutions to enterprises in order to understand firms' drivers of innovation. Notably, based on the conceptual framework outlined above, we predicted the following relations to hold. First, according to the recognition of the positive effect that good institutions exert on economic growth and industrial evolution, we anticipated a positive relation between institutional quality and innovation at the firm level. Second, given the direct positive effect of institutional quality on SIE's internal governance and management, we expected that, as institutional quality improves, innovation will increase at the margin more in SIEs than in private enterprises. These arguments bring us to expect SIEs to be inferior enterprises in their innovation performance compared to private

\section{(footnote continued)}

independently adjudicated, and which are consistent with international human rights norms and standards. It requires, as well, measures to ensure adherence to the principles of supremacy of law, equality before the law, fairness in the application of the law, separation of powers, participation in decision-making, legal certainty, avoidance of arbitrariness and procedural and legal transparency" (United Nations Secretary-General, 2004, par. 6) enterprises under a poor institutional framework. When the quality of institutions is high, SIEs are expected to outperform private enterprises in their capacity to innovate.

\section{The telecommunication industry}

We focus on the global telecom industry. ${ }^{6}$ There are several reasons why this represents an interesting setting to address our research questions. First, this is fast evolving industry where innovation represents a key-determinant for enterprises to grow, expand their business and increase profits (Davies, 1996; Godoe, 2000; Lam and Shiu, 2010). ${ }^{7}$ Second, in past decades the telecom industry has undergone an important pattern of reforms. Traditional state-owned enterprises that used to operate under a legal monopoly have been widely brought to compete in liberalised markets and underwent a process of privatisation, with different degrees of intensity across different countries (Clifton et al., 2011; Florio 2013). This ensures a high level of heterogeneity in corporate ownership among telecom enterprises. Third, the global perspective we adopt allows us to exploit the high institutional heterogeneity characterising the countries where telecom firms operate. The fact that telecom SIEs are located both in countries characterised by high-quality of institutional arrangements (e.g. Swisscom in Switzerland, Deutsche Telekom in Germany, Alcatel and Orange in France) and in countries with a lower institutional setting (e.g. Telecom Egypt in Egypt, Rostelecom in Russia, China Telecom in China) allows to integrate the institutional perspective into the analysis of ownership as a determinant of innovation.

To put the discussion in the context of innovation in the telecommunications industry, we briefly remind some of the drivers of change in the sector. The model prevailing in the 1980s (at a time where fixed telephony was the main technology) was such that the major telecommunication operators (PTO, Public Telecommunication Operators) were highly vertically integrated state-owned companies. They were often supplying the service, owning the network, operating it, and directly producing a part of the equipment. Under the arrangement before the 1990s, R\&D units where typically integrated within the major telecom companies and most of the technological innovations were the result of in-house research on areas as different as switching devices, routers, cables technology, digitalization of the signal, integration with the newly born mobile telephony, and so on. The industry was then affected by a series of disruptive technology shocks, notably between 1985 and 2005. As recalled by Davies (1996), the telecommunication industry was transformed by a cluster of radical innovations pushed from the cost-saving opportunities stemming not only from potential economies of scale and scope, but most of all from the introduction of large technical systems of control composed by high-capacity telephone exchanges, computer databases and signalling systems. Davies recognizes that the main innovation of the telecommunication system involved the introduction of software-based control devices into large scale components, which induced substantial industrial and corporate transformation. Accordingly, Nightingale et al. (2003) acknowledge the importance of control systems to coordinate the traffic and flow of information in complex networks and add that substantial innovation in various sectors derived at

\footnotetext{
${ }^{6} \mathrm{~A}$ firm is considered to operate in the telecom industry when, according to the NACE rev. 2 classification, it belongs to sector 61 "Telecommunications", which includes wired (61.10), wireless (61.20), satellite (61.30) and other (61.90) telecommunication activities.

${ }^{7}$ The introduction of breakthrough technologies has brought to an increasing consumption pattern and, more in general, to radical changes in our daily life and to how people interact in society. Some of the most relevant technological changes in the telecom industry are the Global System for Mobile communications; the World Wide Web; triple-play "telephony, television, and internet access" offer as well as the high-speed wireless communication for mobile phones and data terminals.
} 
the end of the last century from the incorporation of software and microprocessors into control technologies. Notably, the emergence of the internet and, later on, the full integration of internet with smartphones forced telecom providers to shift from circuit switching with dedicated connections between users to packet switching, where information is broken down and reassembled at destination. At the same time the traffic skyrocketed, and the physical networks had to be redesigned, particularly to accommodate billions of new users of mobile devices. For telecom networks the main drivers of evolution in the new highly integrated ICT panorama were reducing latency of the signal, bandwidth and quality of the signal. This had implications for the interconnection of international telephone gateways, internet exchange points, national and local systems, with a complex pattern of innovation in cloud computing, fixed networks (i.e. optical fibre) and wireless access network, fixed wireless access, radio links and telecom satellites. Evidently, all of these changes implied an important restructuring of the value network and the role of R\&D. Notably, several companies in the telecommunication sector became much less vertically integrated with innovation mainly embodied in the equipment they purchase (Fransman, 1994). Thus, they have changed from organizations that pursue innovation and associated patenting activities in-house to organizations that apply technology from complementary industries.

\section{Data and variables}

We combined data from three different sources. The first source is the ORBIS database managed by the Bureau Van Dijk, which contains yearly information on the financial, accounting and corporate characteristics of a large number of international companies. From this data source, we retrieved information related to investments in tangible assets, investments in intangible assets and market shares, firm geographical location, operating revenues, year of incorporation, and whether the firm is listed on a stock market. ORBIS also contains relevant information relating to the patenting activity of companies. Bureau Van Dijk has extended the OECD HAN database (Harmonised Applicants' Names) (Thoma et al., 2010) and provides a reliable matching of patent assignee names (and the corresponding publication numbers) with ORBIS firms. Therefore, our second source of data refers to firm patenting activity. Following previous studies in the analysis of innovation in the telecommunication sector exploiting patent data (see, among the others, Calderini and Scellato, 2005; Nambisan, 2013; Bekkers et al., 2002), we relied on the Worldwide Patent Statistical Database (PATSTAT) to retrieve information on the names of the assignees, publication number, filing dates and number of citations. Finally, we relied on the World Bank's Worldwide Governance Indicators (WGI) database for data on countries' institutional quality. We combined the information collected from the three data sources described above, and we restricted our sample to telecommunication companies (Sectors $61.10,61.20,61.30$ and 61.90 of NACE Rev. 2) with complete information on their variables of interest over the 2007-15 period, thus attaining an unbalanced panel comprising 706 firms from 91 countries (4854 firm-year observations).

As discussed in the preceding sections, we are interested in explaining the innovative activity of firms in the telecommunication sector. Our key outcome variable is the total number of patent applications filed every year by each company in our sample. ${ }^{8}$ While being an imperfect proxy of innovation activity at the firm level, ${ }^{9}$ patents are

\footnotetext{
${ }^{8}$ We restrict our analysis to patents filed in the main patent offices (USPTO, EPO and JPO). On top of ensuring higher quality, stringency and transparency in the evaluation procedure, they grant wider geographical IP protection in the most relevant markets.

${ }^{9}$ Several innovations are not patented and some technologies are not patentable (e.g. mathematical models, computer programs, aesthetic creations). Furthermore, patent measures can be biased by a firm strategic behaviour that,
}

publicly available documents that are collected on a regular basis and measure the direct outcome of the innovation process while allowing for international comparison (Griliches, 1990). Not only, patent data is characterised by the presence of very long historical time series, which show only minor disturbances by occasional changes of patent laws (Kleinknecht et al., 2002). Furthermore, patent counts show a high correlation with other measures of innovative performance at the firm level, such as R\&D spending and new product announcements (Hagedoorn and Cloodt, 2003). We also tested the robustness of our results by controlling for the quality of the patents that are filed at the firm level. To this end, we used the number of granted and qualityweighted (using 3-years and 5-years citations' timeframes) patents.

Although patent-based indicators have been used to proxy for innovation activity by companies by a large body of the literature in the economics and management of innovation in the past decades, we would like to draw the reader's attention on a number of additional caveats when employing them in the analysis of the innovation activity in the telecommunication sector. ${ }^{10}$ Notably, given the structural shifts in the value network of the telecommunication industry highlighted in Section 3 above, using patents as proxy for innovation activity by telecom companies may simply shed light on the changing location of R\&D (from the telecommunication industry to complementary industries such as manufacturers of communication equipment) and it may be less useful as a proxy for innovation for existing telecom firms. A telecommunication network operator may be highly innovative, deploying the latest technology in its networks and enabling the most advanced services, all based on appropriate procurement policies without relying on R\&D directly. This problem is further exacerbated by a traditional drawback of patent data: they are reliable proxy of innovation activity in manufacturing industries but less so in the service sector (Kleinknecht et al., 2002; Hipp and Grupp, 2005). In spite of the above drawbacks, we believe that patent count is still a useful measure to proxy for firm innovation performance in the telecommunication industry. The appendix provides a thorough discussion of why this is the case.

Our first explanatory variable refers to whether the firm is state owned or not. A firm is considered a SIE when it is ultimately owned by a government or public authority, where the ultimate owner is defined as the individual or entity at the top of the corporate ownership structure who exercises ultimate effective control over the company (the ultimate controlling shareholder which holds at least $25.01 \%$ of total (i.e. direct and indirect) ownership). Ownership is thus defined by identifying the owner of the largest share of equity in the company or along the chain of ownership in the controlling firm(s). ${ }^{11}$ This criterion encompasses both enterprises under direct public control, where the government is the top shareholder, ${ }^{12}$ and under indirect public control, where the government is the ultimate owner through a chain of upstream ownership relations while it does not figure as the SIE's top shareholder. ${ }^{13}$

\section{(footnote continued)}

for example, decides not to commercialise a patented invention but only to hold the patent to prevent a competitor to use the technology (Archibugi and Pianta, 1996).

${ }^{10}$ We would like to thank one of the anonymous reviewers for pointing this out.

${ }^{11}$ The ownership of a company is determined by adopting the following procedure. For each year of the 2007-15 period, we extracted information on the firm's top shareholder from ORBIS. The former refers to the owner of the largest share of equity in the company, so we proceeded in a recursive manner until the ultimate controller is identified, especially when such an entity is a governmental body.

${ }^{12}$ This includes, for instance Swisscom (CH), Orange (FR), China Mobile (CN) Nippon Telegraph and Telephone (JP), Temasek (SG), Teliasonera (SE), MobiFone (VT).

${ }^{13}$ e.g. Fastweb (IT) is controlled by Swisscom, a private shareholder which, in 
During the 2007-15 period under analysis, the ownership nature of the firm was very stable (less than $3 \%$ of companies shifted from public to private property, or vice versa), thus lowering the risk of our results being biased by a potential problem of reverse causality (e.g. the possibility that the performance of the firm affects its probability of being privatised or nationalised).

Around $72 \%$ of the sample (3485 firm-year observations) comprises private companies (e.g. Vodafone and British Telecom (UK), Telecom Italia (IT), America Movil (MX)). The remaining 28\% of the sample (1372 firm-year observations) is composed of firms controlled by a government.

The second explanatory set of variables refers to the quality of the government in the country where each firm is located. To measure institutional quality, we followed a consolidated literature and used the World Bank's Worldwide Governance Indicators (WGI) (Kaufmann and Kraay, 2008; Kaufmann et al., 2011). In light of our specific interest in the quality of the government controlling the SIEs, we decided to focus our attention on the Control of Corruption (CC) indicator, which captures "the extent to which public power is exercised for private gain, including both petty and grand forms of corruption, as well as "capture" of the state by elites and private interests" (pag 223, Kaufmann et al., 2011). Nevertheless, the CC indicator is highly correlated with the other WGI indicators, thus pointing to a high degree of overlapping of these measures (the correlation coefficients range between 0.7 and 0.9). Moreover, our main results are broadly confirmed when we consider other WGI indicators, such as government effectiveness (GE); rule of law (RL) and regulatory quality (RQ), or voice and accountability (VA). ${ }^{14}$

We also included a set of variables recognised as relevant to explain patenting activity at the firm level: investment in tangible and intangible (fixed) assets, the firm's total assets, operating revenues, the firm's age, industry concentration and whether the company is listed on a stock market. Investments in firms' assets have been found to be an important factor when explaining their innovative activity (Thornhill, 2006). Although investment in intangible assets is an imperfect measure of R\&D investment at the firm level, it has been used as a proxy of R\&D investment when data on R\&D expenses is not available or affected by self-selection bias as in our case (Leoncini et al., 2019; Marin, 2014). Investment in tangible (intangible) assets come from

\section{(footnote continued)}

turn, is controlled by the Swiss government; as regards Hellenic Telecommunications (GR) the top shareholder is Deutsche Telekom, a private shareholder which in turn is controlled by the German government.

${ }^{14}$ There are undisputable advantages in the use of WGIs. First of all, they are among the most widely used cross-country governance indicators currently available, as they have been employed as proxies for institutional quality in a wide number of peer-reviewed scientific articles. Moreover, they provide information about more than 200 countries for a long time period (1996-2018). Another advantage is that these indicators are based on hundreds of underlying individual indicators drawn from 30 different organizations, relying on responses from tens of thousands of citizens, enterprise managers, and experts. Obviously, there are also drawbacks in the use of these indicators. For example, Knack (2006) mentions that WGI are not suitable for cross-country and overtime comparisons due to a combination of issues in scaling and the difficulty to estimate governance using different data sources. Biased expert assessment is another critical component that has been highlighted by mentioning that WGI indicators are affected by overly emphasis on business regulations, ideological biases as well as upwardly biased scores positively correlated to economic performance (Kurtz and Shrank, 2007). Finally, some authors have suggested that experts make similar errors when assessing the same country, thus leading to within-country correlation in the perception errors (Williams and Siddique, 2006). Despite the issues highlighted above, WGIs are a widely diffused measure of institutional quality with a long historical series and excellent crosscountry coverage. Moreover, many of the concerns raised about WGIs are likely to arise in the context of other existing and proposed efforts to measure institutional quality (Kaufmann et al., 2007). companies' financial statements and have been deflated by using the country-level consumer price index provided by the World Bank (with 2010 as base year). Building upon the extensive literature investigating the determinants of a firm's innovative activity, we control for firm size (measured as the yearly amount of total assets), profitability (operating revenues), age, and firm-level transparency constraints and financial accountability (stock market listing). We also include a popular measure of industry concentration, as the latter has been found to play a relevant role with respect to firms' patenting performance (Aghion et al., 2005; Breschi et al., 2000). A four-firm concentration ratio was computed as the market share of the four largest firms in terms of operating revenues at 2-digit NACE Rev. 2 industry codes each year.

Table 1 reports descriptive statistics for the patenting performance, institutional quality and other relevant firm characteristics for SIEs and non-SIEs, while Figs. 1 and 2 show the geographical distribution of, respectively, firms and patent applications per ownership type. ${ }^{15}$ These descriptive statistics show that SIEs tend, on average, to apply for a higher number of patents compared to private companies. The difference between private and public companies in the number of patent applications is likely to depend on the degree of heterogeneity within the private firms' group. This group includes small companies that have been historically found to have a low propensity to patent the results of innovation activity (Andries and Faems, 2013). When we removed the companies that had not applied for any patent from the descriptive statistics, we found that the average values increase, but the difference between SIEs and private enterprises (POEs) persist. In our sample, private enterprises are, on average, larger in size (in terms of both total assets and operating revenues) and show higher investment in tangible and intangible assets compared to SIEs. The high value of standard deviation shows that this pattern might be driven by some relevant outliers among private companies (notably US telecom enterprises, e.g. AT\&T, Verizon, Centurylink). If we focus on median values, SIEs invest more in tangible assets compared to POEs but have lower operating revenues. Concentration ratio values show that telecom companies mainly compete in oligopolistic markets and that, on average, SIEs operate in more concentrated markets than private companies.

It is interesting to observe that $48 \%$ of the private companies are listed on a stock market, while this percentage increases up to $55 \%$ for SIEs. This suggests that, despite being controlled by a public entity, many SIEs have improved their financial accountability and are increasingly exposed to market incentives through stock market listing. Table 1 also shows that, compared to private companies, SIEs are relatively more concentrated in countries characterised by lower institutional quality (mainly non-OECD countries). The higher standard deviation in institutional quality measures for SIEs suggests that institutional quality is more heterogeneous under public ownership. SIEs can be found both in countries belonging to the lower tail of institutional quality distribution (Egypt, Indonesia, Kazakhstan, Serbia, Russian Federation, Ukraine, Venezuela, Vietnam) as well as the upper tail (Austria, Germany, Finland, France, Japan, Norway, Sweden, Switzerland).

\section{Estimation strategy and results}

We are interested in examining the effect of state ownership, country institutional quality and their interplay on patenting activity at the firm-level. Section 5.1 contains a discussion of our empirical strategy, while Section 5.2 presents our main results on the relationship between ownership type and firm patenting. In the same section we analyse how this relation varies depending on the quality of institutions.

\footnotetext{
${ }^{15}$ As our sample comprises firms from more than 80 countries worldwide, for the sake of clarity, data have been aggregated by macro geographical areas.
} 
Table 1

Descriptive statistics by ownership type - period 2007-2015.

\begin{tabular}{|c|c|c|c|c|c|}
\hline & Median & Mean & SD & Min & Max \\
\hline \multicolumn{6}{|c|}{ Operating revenues (th. \$) } \\
\hline Private Enterprises & 26,838 & 1690,759 & 9609,552 & 0 & $163,800,000$ \\
\hline SIEs & 21,315 & 696,792 & 2130,091 & 0 & $17,830,028$ \\
\hline \multicolumn{6}{|l|}{ Total assets (th. \$) } \\
\hline Private Enterprises & 59,439 & 3415,506 & $20,700,000$ & 0 & $402,700,000$ \\
\hline SIEs & 41,498 & 1480,163 & 4568,302 & 10 & $46,969,852$ \\
\hline \multicolumn{6}{|c|}{ Intangible assets (th. \$) } \\
\hline Private Enterprises & $3243^{* * * *}$ & 1336,742 & $10,400,000$ & 0 & $225,300,000$ \\
\hline SIEs & $2592^{* * * *}$ & 295,869 & 1154,485 & 0 & $98,45,798$ \\
\hline \multicolumn{6}{|c|}{ Tangible assets (th. \$) } \\
\hline Private Enterprises & 9535 & 1198,763 & 7411,236 & 0 & $124,500,000$ \\
\hline SIEs & 12,763 & 518,957 & 1687,615 & 0 & $18,068,106$ \\
\hline \multicolumn{6}{|l|}{ Listed } \\
\hline Private Enterprises & $0.0^{* * *}$ & 0.48 & 0.50 & 0 & 1 \\
\hline SIEs & $1.0^{* * *}$ & 0.55 & 0.50 & 0 & 1 \\
\hline \multicolumn{6}{|c|}{ Year of incorporation } \\
\hline Private Enterprises & 1997 & 1990 & 24 & 1846 & 2014 \\
\hline SIEs & 1995 & 1988 & 27 & 1852 & 2013 \\
\hline \multicolumn{6}{|l|}{ Patent applications } \\
\hline Private Enterprises & $0.0^{\text {**:** }}$ & 6.6 & 61.7 & 0.0 & 1571.0 \\
\hline SIEs & $0.0^{* * * *}$ & 55.1 & 375.4 & 0.0 & 4035.0 \\
\hline \multicolumn{6}{|c|}{ Control of corruption ${ }^{\mathrm{a}}$} \\
\hline Private Enterprises & $82^{* * * *}$ & 73 & 23 & 2 & 100 \\
\hline SIEs & $62^{* * * *}$ & 63 & 26 & 1 & 100 \\
\hline \multicolumn{6}{|c|}{ Concentration ratioCR 4} \\
\hline Private Enterprises & $0.89^{* * * *}$ & 0.84 & 0.17 & 0.32 & 1.00 \\
\hline SIEs & $0.94^{* * * *}$ & 0.88 & 0.15 & 0.32 & 1.00 \\
\hline
\end{tabular}

a Institutional quality indicators refer to the country of the enterprise and are reported in percentile rank terms, ranging from 0 (lowest rank) to 100 (highest rank).

*** Difference significant at $1 \%$ level according to Wilcoxon rank-sum test. for:

$\operatorname{Pr}(Y=y)=\frac{e^{-\mu} \mu^{y}}{y !}$

with $E[Y]=\operatorname{var}[Y]=\mu$

Adopting a Poisson regression model, we specify the conditional mean in the following formula:

$E\left[P A T_{i, t}\right]=\exp \left(\alpha+\beta S I E_{i, t}+X_{i, t}^{\prime} \gamma+\delta Z_{c}+\theta Y_{t}\right)$

where the dependent variable is the expected number of $P A T_{i, t}$, the number of patents filed by firm $i$ in year $t . S I E_{i, t}$, takes the value of 1 when the firm is controlled by a government and zero otherwise. The vector $X_{i, t}$ includes the set of control variables described in Section 4 which have been log-transformed for estimation purposes. As for firmlevel controls, the size of the company is proxied by its operating revenues. Tangible assets measure the firm's capital expenditures; intangible assets are used as a proxy for internal R\&D effort, since data on $R \& D$ expenditures are missing for most of the firms composing our sample. We also considered the age of the firm and whether the firm is listed on a stock exchange. As for country level controls, we included the concentration ratio $\mathrm{CR}_{4}$, which measures the market share of the four largest firms in terms of operating revenues for each year and country. Time and geographical fixed-effects were added to control for potential confounding factors and for correlated unobserved heterogeneity. Year fixed-effects $Y_{t}$ capture time-dependent common shocks including macroeconomic exogenous shocks (2007-15), while $Z_{c}$ are country level fixed effects (85 countries).

Given the positive-skewed distribution with a long right tail, we first adopted the Poisson model as the main estimation approach with standard errors being robust to heteroskedasticity. Although our de-

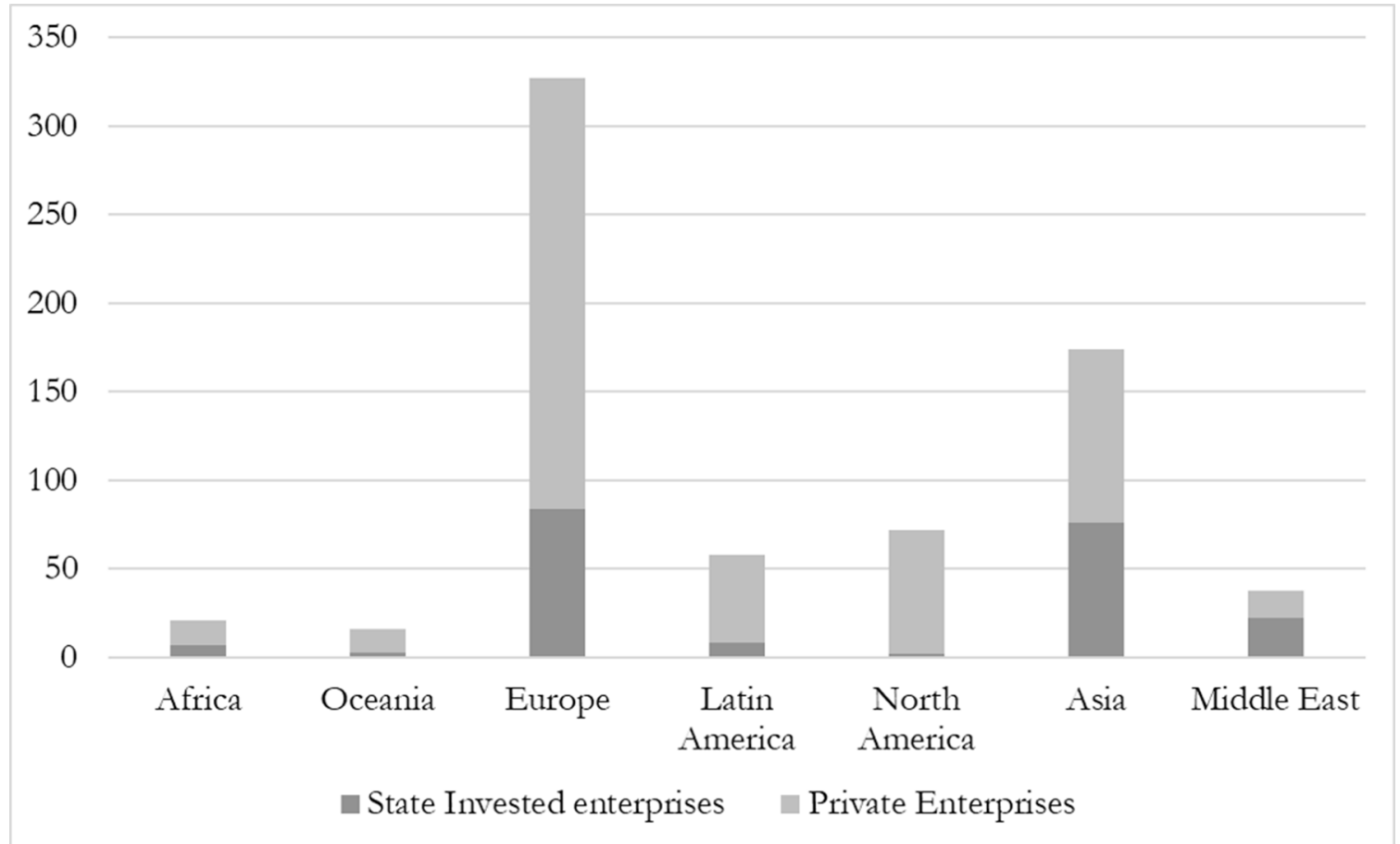

Fig. 1. Number of firms by ownership type and macro geographical area. Source: own elaboration on Bureau Van Dijk.

\subsection{Model specification}

To study the relationship between firms' ownership and its patenting activity, and given the count nature of the dependent variable (number of patents) containing positive and integer values, we rely on a Poisson specification to model the number of patents $(y)$ a firm applies pendent variable shows a departure from the assumption of equi-dispersion (i.e. the mean and variance of our dependent variable are significantly different) characterising Poisson regression models, recent work has consistently shown that the Poisson regression model has several advantages compared to alternative regression models (e.g. negative binomial). The Poisson regression model provides consistent 


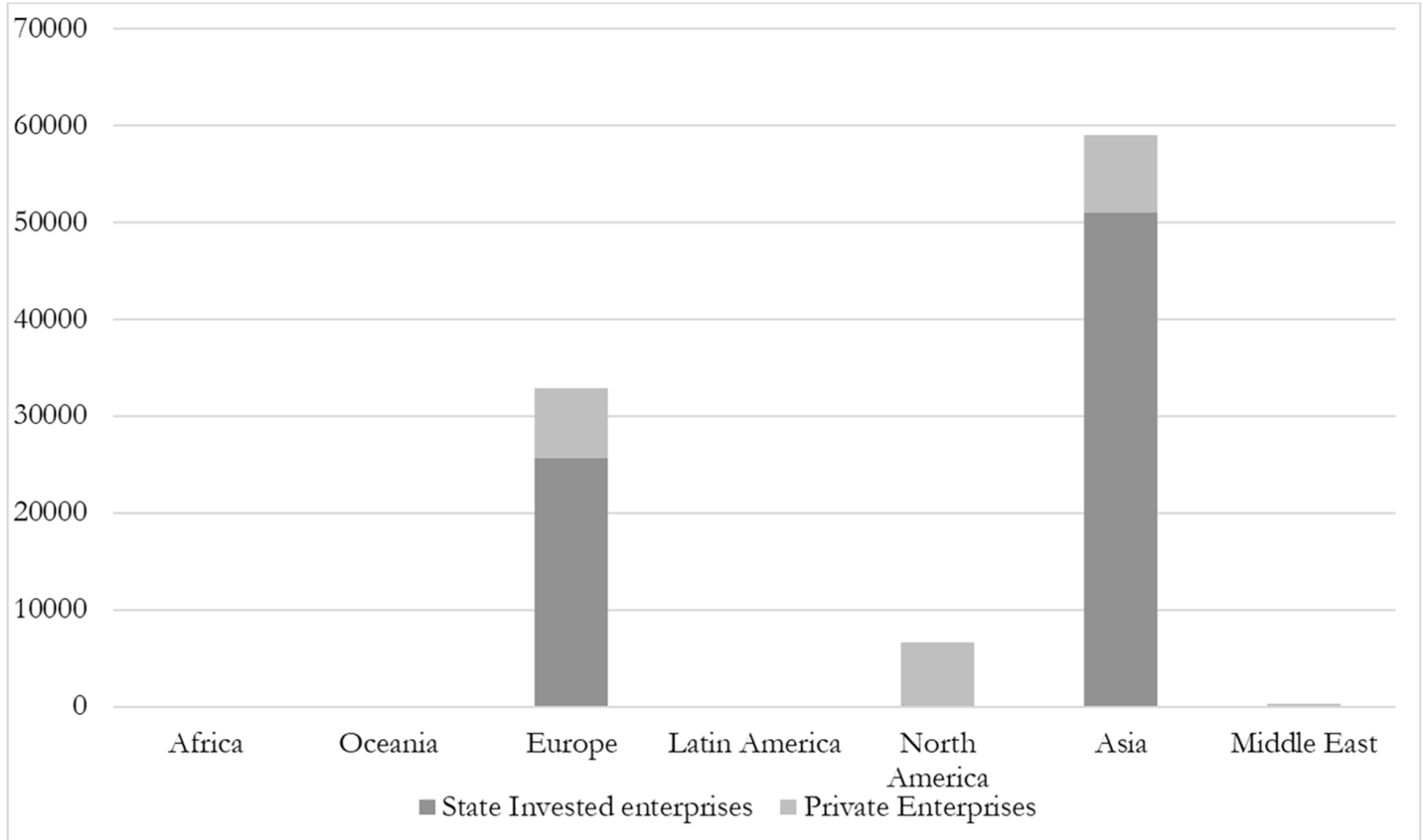

Fig. 2. Number of patents by ownership and macro geographical area - period 2007-15. Source: own elaboration on Bureau Van Dijk and Patstat.

estimates of coefficients of interest even when the underlying distribution of the dependent variable is not Poisson but the conditional mean is correctly specified (Gourieroux et al., 1984; Wooldridge, 1999). ${ }^{16}$ Moreover, the Poisson regression model is robust to a number of misspecifications such as over-dispersion (it can be accommodated by using robust standard errors), the presence of an excessive number of zeros, and to dependence over time as well as cross-sectional dependence (Bertanha and Moser, 2016).

Then, we extended the baseline model by adding institutional quality measures and interacting them with the ownership variable (Eq. (2)). This allowed us to assess whether the change in institutional quality differentially affects the patenting activity of private companies compared to SIEs.

$$
\begin{aligned}
& \mathrm{E}\left[P A T_{i, t}\right] \\
& \quad=\exp \left(\alpha+\beta S I E_{i, t}+\mu I N S T_{i, t}+\vartheta S I E_{i, t} I N S T_{i, t}+X_{i, t}^{\prime} \gamma+\delta Z_{c}+\theta Y_{t}\right)
\end{aligned}
$$

\subsection{Results and discussion}

Table 2 contains the results from the models above. Column 1 reports the baseline knowledge production function. Results show that the number of patents is positively and significantly associated to the size of the firm (measured by the log of operating revenues), the intensity of R\&D internal effort (proxied by the log of intangible assets) and firm age. Being listed on a stock market is positively associated to patenting activity. Listed companies manage to attract a larger amount of private equity and become more financially accountable. Both phenomena contribute to explaining this result. Market competition is also

\footnotetext{
${ }^{16}$ The same does not hold for the Negative Binomial, i.e. when the dependent variable is not gamma distributed, the coefficient of interest is not consistently estimated even if the conditional mean is correctly specified.
}

Table 2

\begin{tabular}{|c|c|c|c|c|}
\hline & (1) & (2) & (3) & (4) \\
\hline Tangible Assets & $\begin{array}{l}-0.229^{* * *} \\
(0.053)\end{array}$ & $\begin{array}{l}-0.164^{* * * *} \\
(0.041)\end{array}$ & $\begin{array}{l}-0.220^{\text {**** }} \\
(0.040)\end{array}$ & $\begin{array}{l}-0.250^{* * *} \\
(0.040)\end{array}$ \\
\hline Intangible Assets & $\begin{array}{l}0.150^{* *} \\
(0.059)\end{array}$ & $\begin{array}{l}0.058 \\
(0.039)\end{array}$ & $\begin{array}{l}0.157^{* * * *} \\
(0.046)\end{array}$ & $\begin{array}{l}0.182^{* * * *} \\
(0.043)\end{array}$ \\
\hline Operating Revenues & $\begin{array}{l}0.392^{* * *} \\
(0.076)\end{array}$ & $\begin{array}{l}0.322^{\text {***** }} \\
(0.074)\end{array}$ & $\begin{array}{l}0.408^{\text {***** }} \\
(0.091)\end{array}$ & $\begin{array}{l}0.436^{\text {***** }} \\
(0.085)\end{array}$ \\
\hline Age & $\begin{array}{l}1.126^{\text {*** }} \\
(0.159)\end{array}$ & $\begin{array}{l}0.840^{\text {*非 }} \\
(0.123)\end{array}$ & $\begin{array}{l}0.841^{\text {***** }} \\
(0.123)\end{array}$ & $\begin{array}{l}0.821^{\text {***** }} \\
(0.125)\end{array}$ \\
\hline Listed & $\begin{array}{l}1.791^{\text {**** }} \\
(0.265)\end{array}$ & $\begin{array}{l}1.836^{\text {**** }} \\
(0.227)\end{array}$ & $\begin{array}{l}1.769^{\text {***** }} \\
(0.223)\end{array}$ & $\begin{array}{l}1.917^{\text {*粎 }} \\
(0.230)\end{array}$ \\
\hline Concentration Ratio & $\begin{array}{l}-5.073^{* * * *} \\
(0.903)\end{array}$ & $\begin{array}{l}-4.103^{* * *} \\
(0.647)\end{array}$ & $\begin{array}{l}-2.126^{* *} \\
(0.846)\end{array}$ & $\begin{array}{l}-1.444 \\
(0.902)\end{array}$ \\
\hline SIE & & $\begin{array}{l}1.684^{* * * *} \\
(0.169)\end{array}$ & $\begin{array}{l}1.563^{* * * *} \\
(0.152)\end{array}$ & $\begin{array}{l}-12.367^{* * * * *} \\
(2.128)\end{array}$ \\
\hline Control of Corruption (CC) & & & $\begin{array}{l}0.095^{\text {**** }} \\
(0.016)\end{array}$ & $\begin{array}{l}-0.020 \\
(0.015)\end{array}$ \\
\hline SIE ${ }^{* C C}$ & & & & $\begin{array}{l}0.155^{\text {***** }} \\
(0.023)\end{array}$ \\
\hline Constant & $\begin{array}{l}-2.988^{* *} \\
(1.257)\end{array}$ & $\begin{array}{l}-2.464^{\text {***** }} \\
(0.910)\end{array}$ & $\begin{array}{l}-14.280^{* * * *} \\
(2.703)\end{array}$ & $\begin{array}{l}-4.870^{* * *} \\
(2.396)\end{array}$ \\
\hline Observations & 4854 & 4854 & 4854 & 4854 \\
\hline Year and Country FEs & YES & YES & YES & YES \\
\hline Pseudo Rsq & 0.820 & 0.846 & 0.872 & 0.881 \\
\hline
\end{tabular}

The role of institutional quality and public ownership in firm patenting activity.

**** $p<0.01$.

*** $p<0.05$.

${ }^{*} p<0.1$; Robust standard errors are reported in parentheses.

found to be positively associated with firm-level patenting activity, as an increase in the market concentration index is associated with a reduction in the number of patents. These results favour a picture of the telecom industries with low market concentration, high firm size and positive role of internal R\&D for innovation which can be entirely assimilated neither to a "Schumpeter Mark I" nor to a "Schumpeter Mark II" pattern of innovation. This lack of a clear result in the pattern of 
innovation of the telecommunication sector resonates well with results from previous work (Malerba and Orsenigo 1994, 1996).

In Column 2 of Table 2 we test our research question relating to the differential role of public ownership on firm-level patenting activity and controlling for major potential confounding factors. Variable $S I E_{i, t}$ has a positive and significant coefficient, suggesting that public ownership is associated with higher patenting activity compared to the private benchmark.

Column 3 of Table 2 shows the results of our estimation when a measure for the quality of government is added to the knowledge production function. Results show that the "control of corruption" WGI indicator has a positive and significant coefficient, supporting the argument that improvement in the quality of institutions is positively associated with firm patenting performance. This result is confirmed in the next version of the model, where the public ownership variable interacts with the institutional quality variable (Columns 4). When focusing on the ownership dimension of the firm, two interesting results emerge. First, the coefficient of the public ownership variable is negative and significant, pointing to a lower intercept for SIEs. This suggests that when looking at countries with lower institutional quality, SIEs innovate less compared to private companies. Conversely, the coefficients of the interaction between public ownership and institutional quality measures is found to be positive and significant. An increase in the level of institutional quality at the country-level contributed to patenting performance more for SIEs than for private companies. This result is consistent with our conceptual framework and we interpret it in the light of the double relation (internal and external) connecting the quality of institutions to SIEs. Under an improved institutional environment, both SIEs and private firms benefit from being located in a safer place where they can develop their business, but only SIEs seem to take advantage of an improved internal governance and organisational model for patenting purposes. Only in a high institutional setting are SIEs less prone to political capture, more likely to be managed efficiently, and committed to long term stringent social goals, resulting in a higher patenting performance. These results show that a firm's attitude towards patenting crucially depends both on its internal institutions, which are ultimately affected by ownership identity, and on the quality of the institutional environment where the firms operate.

In Table 3 we confirmed that our results are valid when other five different WGI measures of institutional quality are considered. Results show that, irrespectively from the chosen indicator, the quality of institutions is always positively associated with firm patenting activity, with a differential impact across SIEs and private enterprises. ${ }^{17}$

\section{Robustness checks}

\subsection{Endogeneity}

Our results show that the firms' patenting behaviour is positively associated with public ownership. However, this result would be biased if the ownership structure was endogenous with respect to the firm's patenting activity: it may be the case that differences across firms in their patenting activity influenced the decision to privatise before 2007 . For example, state-owned companies characterised by a bad performance may have been converted into private firms more likely. If this is the case, governments would have continued to keep into their hands the best performing enterprises and the results from our estimates

\footnotetext{
${ }^{17}$ We have also checked the robustness of our results to the use of other institutional quality indicators: regulatory quality indicators which are specific to the telecom industry. Notably, we introduce alternative indicators from the Information and Communication Technologies (ICT) Regulatory Tracker developed by the UN agency International Telecommunication Union (ITU) (Faccio and Zingales, 2017; Castelnovo et al., 2019). Our main results are confirmed and provided in Tables A5 and A6 of the supplementary material.
}

would have been the output of this different behaviour. Indeed, the evidence we provide for the period 2007-15 that public ownership is positively correlated with the patenting behaviour would depend on the fact that, in the past, less innovative SOEs were privatised, thus affecting negatively the patenting performance of the firms that, in our considered period, are identified as private.

To address this potential endogeneity issue, we provide three different sets of arguments. First of all, we claim that our period of analysis is not subject to relevant changes in the privatisation of the chosen companies. In fact, our analysis is carried out for the period 2007-15, when the ownership structure of the firms under consideration remains quite stable. This would partially rule out the possibility that the ownership of the firm changed during the considered period because of their patenting activity and thus inducing an endogeneity problem in our estimates. A second argument, more qualitative in nature, comes from our analysis of the existing literature. We find ample support for the argument that the best performing SOEs were privatised more often than the worst performing ones. This has been often referred in the popular press as the "selling off the family silver" argument. ${ }^{18}$ For example, Obinger et al., 2016 show that, when partisan political groups are involved into the decision to privatise, one of the most frequent rationales is the need by government to soften budgetary constraints via revenues deriving from privatisation. Following this, SOEs with higher market value potential are found to be privatised first, while the divestiture of loss-making companies has been often delayed until a complete financial restructuring was done (so that financial investors could find them more attractive). Similarly, Megginson and Netter (2001) and Florio, 2004 claim that the divestiture of British Telecom in the UK was the 'mother of all privatisations' because it was extremely attractive to investors. When looking at the non- European context, Ure, 2003 discusses telecom privatizations in Asia. The authors highlight a long list of determinants of privatisation decision, all with fund raising or cost cutting purposes, without a clear implicit correlation between the timing of privatization and company performance.

Overall, the literature does not support the view that less performing firms are more likely to be privatised compared to best performing ones. As it is widely acknowledged the important role of technological innovation to economic performance (Griliches, 2007; Freeman and Soete, 1997; Archibugi and Michie, 1998), we expect the performance of a company in a technological industry such as telecommunications to be correlated with the level of patenting. Following this, we most likely expect the decision to privatise a SOE either to be not correlated with its patenting activity (the decision to privatise is not related to economic performance/patenting) or to be positively correlated (it is the best performing/innovative companies that are privatised following the "selling off the family silver" argument). In the first case (no correlation) our estimates would be unbiased, while in the second case (positive correlation) our estimates would be downwardly biased. In any case, on the basis of the evidence provided by the existing literature, we feel confident to reject a problem of endogeneity which points in the direction of an upwardly bias of our estimates. This would mean the existence of a negative correlation between the decision to privatise SOEs and the level of patenting of the company (i.e. it is the worst performing companies which are more likely to be privatised), an association which finds no support in the vast literature on privatisation in developed and developing countries.

Our third step in the analysis of a potential problem of endogeneity, rests on a quantitative robustness check of our results. As the potential bias depends on the fact that some public assets were transferred into

\footnotetext{
${ }^{18}$ During a famous public speech to the Tory Reform Group on Margaret Thatcher's Privatization policies, the former UK prime Minister Harold Macmillan referred to the privatization process as a decision to sell off the family silver ("Stockton attacks Thatcher policies", The Times, 9 November 1985, p. 1)
} 
Table 3

Alternative institutional indicators.

\begin{tabular}{|c|c|c|c|c|c|}
\hline & (1) & (2) & (3) & (4) & (5) \\
\hline SIE & $\begin{array}{l}-11.176^{\text {****** }} \\
(2.189)\end{array}$ & $\begin{array}{l}-16.183^{\text {**** }} \\
(2.577)\end{array}$ & $\begin{array}{l}-5.975^{*} \\
(3.072)\end{array}$ & $\begin{array}{l}-5.397^{\text {*** }} \\
(2.201)\end{array}$ & $\begin{array}{l}-1.722^{*} \\
(1.009)\end{array}$ \\
\hline Government Effectiveness (GE) & $\begin{array}{l}-0.020 \\
(0.023)\end{array}$ & & & & \\
\hline $\mathrm{SIE}^{*} \mathrm{GE}$ & $\begin{array}{l}0.141^{\text {***** }} \\
(0.025)\end{array}$ & & & & \\
\hline Rule of Law (RL) & & $\begin{array}{l}-0.017 \\
(0.020)\end{array}$ & & & \\
\hline SIE*RL & & $\begin{array}{l}0.199^{\text {**** }} \\
(0.029)\end{array}$ & & & \\
\hline Regulatory Quality (RQ) & & & $\begin{array}{l}0.074 \\
(0.034)\end{array}$ & & \\
\hline SIE*RQ & & & $\begin{array}{l}0.088^{* *} \\
(0.036)\end{array}$ & & \\
\hline Voice and Accountability (VA) & & & & $\begin{array}{l}0.015 \\
(0.024)\end{array}$ & \\
\hline SIE*VA & & & & $\begin{array}{l}0.083^{\text {***** }} \\
(0.026)\end{array}$ & \\
\hline Absence of Political Violence (APV) & & & & & $\begin{array}{l}0.048^{* * *} \\
(0.013)\end{array}$ \\
\hline SIE*APV & & & & & $\begin{array}{l}0.043^{* * * *} \\
(0.014)\end{array}$ \\
\hline Constant & $\begin{array}{l}-5.755^{* *} \\
(2.836)\end{array}$ & $\begin{array}{l}-5.543^{* *} \\
(2.388)\end{array}$ & $\begin{array}{l}-13.996^{* * * *} \\
(2.835)\end{array}$ & $\begin{array}{l}-8.768^{* * *} \\
(2.336)\end{array}$ & $\begin{array}{l}-9.321^{\text {****}} \\
(2.030)\end{array}$ \\
\hline Observations & 4854 & 4854 & 4854 & 4854 & 4854 \\
\hline Year and Country FEs & YES & YES & YES & YES & YES \\
\hline Pseudo R-sq & 0.882 & 0.883 & 0.885 & 0.887 & 0.871 \\
\hline
\end{tabular}

*** $p<0.01$

** $p<0.05$.

${ }^{*} p<0.1$; Robust standard errors are reported in parentheses. The following explanatory variables are included in the regressions although their coefficients have

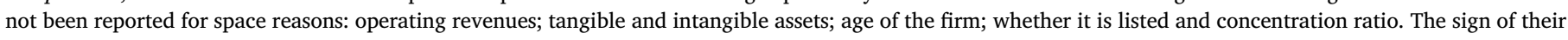
coefficient is consistent with the results presented in Table 2.

private hands in the past, we re-run our main regressions by excluding from the sample those firms that have been privatized in the years preceding our period of reference. In this way, we exclude the possibility that our results are driven by the historical decision to privatize depending on the firms' performance. ${ }^{19}$ We identify 149 firms belonging to our sample which have been privatised over the period 1980-2007, totalling 1014 firm-year observations, which have been promptly excluded from our sample for the purpose of our robustness check. We re-run our main regressions on this smaller sample comprising 3844 firm-year observations. We report the results in Table 4. Results confirm our main findings and hence provide further support for the robustness of our estimates to the endogenous ownership shift depending on firms' patenting activity. By removing private companies which are the result of a privatisation process, in these estimates we compare state-invested enterprises only to private firms which have not undergone any privatization process. Interestingly, the SIE coefficient (Column 1, Table 4) is 1.3 points higher than the one estimated using the whole sample (Column 2, Table 2). This change seems to be

\footnotetext{
${ }^{19}$ To run this robustness check, we had first to identify the telecom enterprises belonging to our sample that have been privatised in the period 19802007 , as before this period no relevant privatisations took place in the telecommunication sector (Koske et al., 2015). We retrieve this information from three different data sources. First, we rely on the Bureau Van Dijk's Zephyr dataset, which reports worldwide information on completed deals (i.e. IPOs or acquisitions). We identify all the telecom enterprises from our sample which have been targeted in a M\&A in the period 1980-2007 and, because of that, have changed their ownership status from public to private. We merge this information with data from the Privatization Barometer, an internet portal launched in 2003 and recently acquired and managed by KPMG, which reports detailed information on the privatisations which took place in the OECD area over the period 1980-2007. Finally, we cross-checked the reliability of the collected data with information from the Wikipedia list of privatisation by country
}

Table 4

Robustness check with no privatised firms.

\begin{tabular}{llll}
\hline & $(1)$ & $(2)$ & $(3)$ \\
\hline Tangible Assets & $-0.146^{* * *}$ & $-0.193^{* * * *}$ & $-0.211^{* * *}$ \\
& $(0.056)$ & $(0.052)$ & $(0.053)$ \\
Intangible Assets & -0.064 & 0.057 & 0.072 \\
& $(0.082)$ & $(0.080)$ & $(0.078)$ \\
Operating Revenues & $0.520^{* * *}$ & $0.548^{* * *}$ & $0.556^{* * * *}$ \\
& $(0.114)$ & $(0.123)$ & $(0.123)$ \\
Age & $0.862^{* * *}$ & $0.895^{* * *}$ & $0.882^{* * *}$ \\
& $(0.171)$ & $(0.195)$ & $(0.193)$ \\
Listed & $4.018^{* * *}$ & $3.806^{* * *}$ & $3.947^{* * *}$ \\
& $(0.338)$ & $(0.296)$ & $(0.299)$ \\
Concentratio Ratio & $-6.479^{* * *}$ & $-2.770^{* *}$ & $-2.691^{* *}$ \\
& $(0.818)$ & $(1.081)$ & $(1.069)$ \\
SIE & $3.047^{* * *}$ & $2.801^{* * *}$ & $-11.986^{* * *}$ \\
& $(0.367)$ & $(0.374)$ & $(4.981)$ \\
Control of Corruption $(C C)$ & & $0.109^{* * * *}$ & -0.045 \\
SIE*C & & $(0.019)$ & $(0.050)$ \\
& & & $0.165^{* * *}$ \\
Constant & & & $(0.055)$ \\
& $-6.688^{* * * *}$ & $-20.589^{* * *}$ & -6.996 \\
Observations & $(2.198)$ & $(3.988)$ & $(5.156)$ \\
Year and Country FEs & 3840 & 3840 & 3840 \\
Pseudo R-sq & YES & YES & YES \\
& 0.908 & 0.924 & 0.927 \\
\hline
\end{tabular}

$$
\begin{aligned}
& { }^{* * * *} p<0.01 \\
& { }^{* * *} p<0.05 . \\
& { }^{*} p<0.1 \text {. Robust standard errors are reported in parentheses. }
\end{aligned}
$$

coherent with the "selling off the family silver" argument and suggests that, at most, our previous results were biased downwards, as the inclusion among the private firms of the best performing privatised SIEs could bring to an underestimation of the correlation between public 
ownership and patenting activity. ${ }^{20}$

\subsection{Other robustness checks and supplementary analyses}

As a further check, we verified the robustness of our results to several alternative specifications. For ease of exposition, the results are shown by the last specification of the model where the type of public control is specified and interacted with the Control of Corruption institutional variable although the results are broadly confirmed when adopting other institutional quality indicators. ${ }^{21}$

The first set of robustness checks pertains to the nature of the dependent variable. Although the Poisson regression has demonstrated to be a specification that is quite robust to the excess of zeroes (as well as over-dispersion and departure from Poisson distribution - see Bertanha and Moser, 2016), we carried out an additional control for potential problems arising from a disproportionate number of zeros in our dependent variable (out of 707 companies, 595 have never applied for a patent in the considered period. The percentage of zero patenting increases up to $90 \%$ when considering firm-yearly observations). To this purpose, we ran our set of estimates, adopting both Zero-Inflated Poisson and Hurdle specifications (Cameron and Trivedi, 2005). While the former permits the decision to not patent in a mixture of Poisson and logit models, the latter keeps the decision to patent separated from the process generating the positive outcomes. Table A1 of the online supplementary material presents results for the two models, both of which confirm our main findings.

Second, in light of the low within variation of our main explanatory variable, we considered whether unobserved heterogeneity represents an issue in our estimates. We adopted a pre-sample mean estimator (Blundell et al., 2002) in which the inclusion of the firm's pre-sample mean of patent applications among the explanatory variables proxies for the unobserved difference among firms in their ability to patent and allows us to control for possibly correlated, time-invariant heterogeneity. Table A2 of the online supplementary material shows a positive and significant effect of patent pre-sample mean. More importantly, even after capturing the firm-specific effect through the pre-sample mean, our main results are confirmed. Improvements in institutional quality increase the patenting performance of SIEs at a faster pace compared to private firms.

Third, we evaluated whether our results are robust when the quality of patent applications, and not only the simple count of patent applications, is taken into consideration. To do so, we resorted to a consolidated literature that developed a number of indicators to proxy for the quality of patents companies apply for (Squicciarini et al., 2013; Lanjouw and Schankerman, 2004). For the purpose of our robustness check, we relied on three main indicators: the number of granted patents and the number of patent applications weighted by the number of citations received in forward 3- and 5- year windows. The results reported in Table A3 of the online supplementary material support our main results.

We also considered whether our results are driven by some relevant outliers (e.g. firms with a particularly intensive patenting activity) given the long fat tails in the distribution of patent applications. ${ }^{22}$ Therefore, we tested the robustness of our results by trimming the right tail of the patent distribution. Table A4 of the online supplementary material shows that our results are also confirmed when yearly

\footnotetext{
${ }^{20}$ These findings are confirmed when we employ alternative institutional quality variables. Results are available from the authors upon request.

${ }^{21}$ Results are available from the authors upon request.

${ }^{22}$ The Skewness/Kurtosis tests for normality reject the hypothesis that the patent-counting variable is normally distributed. While both values depart from those typical of a normal distribution, Kurtosis is much larger (around 500, compared to a value of 3 ), thus supporting the presence of fat tails in the patent distribution.
}

observations with more than 500 patent applications are excluded from our sample, leading us to 4810 firm-year observations. ${ }^{23}$

Finally, we tested the robustness of our results to alternative definitions of public ownership. In our work, a firm is classified under public control when its ultimate owner is a public body. Given this broad definition, the SIE cluster encompasses enterprises with different intensity of government control, measured by the number of shares owned by the government. This heterogeneity might somehow affect our results, sine the capacity of the government to effectively control the SIE and to influence its strategies might depend on the number of shares owned by the government. ${ }^{24}$ To explore this issue, we replace the SIE dummy variable with the percentage of shares owned by a public body, which equals zero in the case of private enterprises and we investigate whether the patenting activity is correlated with the percentage of shares owned by the SIEs' top shareholder. Results reported in Table A7 of the online supplementary material are consistent with our previous findings. We further explore this issue and check whether the relation between patenting activity and public ownership is linear in the percentage of public shares. For this purpose, rather than using a continuous variable, we create a categorical variable (please refer to Section 1.2.2 of the online supplementary material). Results are reported in Table A8 of the online supplementary material. Interestingly, we find that patent applications increase with public control when public ownership is mixed and open to private equity. Consistently with previous findings, this seems to suggest that it is the mixed ownership with partnership among private and public investors, rather public ownership per se, the crucial ingredient that explains the increase in patenting activity (Brander et al., 2015; Bertoni and Tykvová, 2015).

\section{Conclusions}

This paper contributes to the current debate on the role of governments in supporting innovation by taking a novel research avenue. A wide and well-established macroeconomic literature points respectively to the role of innovation and of institutions as facilitators of growth. We extend this literature by combining these intuitions in a firm-level frame of analysis. By considering patents as an empirical, albeit imperfect, proxy of knowledge creation by firms, our findings confirm that the quality of government is indeed correlated with the patenting performance of major telecommunication companies worldwide. This is per se an interesting result because the telecommunication industry has been pivotal in changing modern economies through the transition from analogue telephony to digital information and the internet economy.

Ownership of firms is per se an institutional arrangement, and the quality of firms' governance should be correlated to their performance, including their patenting performance. Previous literature largely supported the full privatisation of state-owned enterprises by pointing to the low quality of their governance. The divestiture of British Telecom by the Thatcher government more than thirty years ago has been defined 'the mother of all privatizations' (Megginson and Netter, 2001). However, governments around the world are still the ultimate owners or top shareholders of major telecom companies. We find that the patenting performance of SIEs, while often inferior to that of their private counterparts, is strongly affected by the quality of government. We interpret this result in accordance to Borghi et al. (2016) who suggest

\footnotetext{
${ }^{23}$ Given the widespread geographical distribution of the enterprises and the resulting low number of observations that are obtained once country institutional variables are introduced, we wanted to exclude the possibility of our results being driven by few enterprises located in specific countries. To address this issue, we also ran our main specification: (i) with institutional quality indicators aggregated in quintiles; and (ii) by replacing them with a binary variable that allows enterprises located in the top 25 institutional countries to be distinguished from the others. The results are consistent with previous findings and available upon request.

${ }^{24}$ We thank two anonymous reviewers for pointing this out.
} 
that while any firm may enjoy the benefits of good government in terms of a favourable external environment, there is an additional specific effect for SIEs. They directly benefit from quality of government in terms of being subjected to less political interference in the appointment of managers and of transparency of the public mission that is assigned to them.

For the first time in the literature, we empirically study to what extent public control of SIEs can reverse the traditional negative perception of SIEs in terms of patenting when the government is of high quality. In fact, we find that when the government of a country with good institutions (low corruption, high government effectiveness, high rule of law, good regulatory quality, good voice and accountability, high political stability) controls a major telecommunication company, this company is able to benefit more from knowledge creation than its private counterpart.

This novel and striking finding, which goes against a mainstream tenet about the low performance of SIEs, suggests that government ownership may act as a 'patient investor' mechanism against the shorttermism of private ownership. This result matches very well with a recent stream of empirical literature that has found decreasing R\&D expenditures in privatised firms. In fact, we find that there is no difference in the patenting activity of private and partially privatised telecommunication companies.

Our results are confirmed when we exclude the privatised firms from the analysed sample. We adopt this strategy to mitigate the risk of our results being biased by a problem of ownership endogeneity. We acknowledge that there may still be some source of endogeneity that we cannot control for with the available data. Future research should consider as a separate topic the drivers of ownership changes, possibly extending the data back in time to when the worldwide telecommunication industry experienced ownership changes (see for example Millward, 2005, 2011, Finger and Kunneker, 2011).

We do not wish to draw any strong policy implications from our results. We are not claiming that SIEs are always more innovative than their private counterparts, as in fact we find the opposite to be true when considering countries with poor institutional quality. Our findings underline that improvements in institutions and in SIEs' internal governance (see e.g. OECD, 2015) can be an alternative to (full) privatisation in enhancing dynamic efficiency within a firm, particularly when divestiture of government ownership is not desirable. These reasons may include adverse stock market conditions, security concerns, and an advantage for the government to earn a dividend instead of corporate taxation when there is fiscal competition among jurisdictions. Overall, future research should explore this question: to what extent could a mission-oriented innovation policy in countries with high quality of institutions include reformed public enterprises in its scope? To what extent an innovation public mission for (partially) stateowned enterprise can be considered as an alternative or a complement to subsidies or other incentives to the R\&D of private or fully privatized firms? These questions are even more important now, given the increasing evidence on the decline of R\&D in some privatised network industries (Jamasb and Pollitt, 2011).

In this perspective, the government's partial ownership of firms in some industries may enable it to play the role of a patient investor, which is known to be favourable to corporate innovativeness, and may be a less costly approach than to offer R\&D subsidies to private firms (with unavoidable principal-agent issues). Further research is needed to assess the cost and benefits of such a policy, particularly in network industries of strategic importance such as telecommunications, energy, and possibly transport.

\section{CRediT authorship contribution statement}

Stefano Clò: Conceptualization, Data curation, Writing - original draft, Software, Formal analysis, Writing - review \& editing. Massimo Florio: Supervision, Conceptualization, Writing - review \& editing, Writing - original draft. Francesco Rentocchini: Methodology, Writing - review \& editing, Software, Formal analysis, Writing - original draft.

\section{Declaration of Competing Interest}

The authors whose names are listed immediately below certify that they have NO affiliations with or involvement in any organization or entity with any financial interest (such as honoraria; educational grants; participation in speakers' bureaus; membership, employment, consultancies, stock ownership, or other equity interest; and expert testimony or patent-licensing arrangements), or non-financial interest (such as personal or professional relationships, affiliations, knowledge or beliefs) in the subject matter or materials discussed in this manuscript.

\section{Supplementary materials}

Supplementary material associated with this article can be found, in the online version, at doi:10.1016/j.respol.2020.103960.

\section{Appendix - Patent data in the telecommunication industry}

Apart from the standard argument of data availability (patent data is publicly available in long time series and can be linked to existing firm level datasets), patent data has the advantage of providing a good picture of firms' technological trajectories both across time and space given the stability of the requirements to obtain patents through time and across countries (Kleinknecht et al., 2002). More importantly, the use of patent count to measure innovation would affect our estimates especially if the vertical integration strategy and the decision to outsource or to maintain internally a R\&D division changed significantly among private and public firms following the structural changes affecting the telecommunication industry since the 1980s. We have to recognize that our analysis focuses on telecommunication companies providing wired (NACE 61.10), wireless (NACE 61.20), satellite (NACE 61.30) and other (NACE 61.90) telecommunication activities, while companies providing communication equipment (manufacture of computer, optical products, electronic components and boards, communication equipment or consumer electronics) are not included into our sample. This implies that the patenting activity of the telecom companies composing our sample is not likely to embed the main technological breakthrough that contributed to change radically the telecommunication sector, i.e. software and microprocessors were not developed by telecom companies. If private telecom companies were to externalize R\&D activity more than SOEs following the structural shifts happening in the industry (technological breakthroughs, privatisations, change in corporate structure, etc.), the difference between private firms and SOEs in patenting performance would be explained by this change rather than the arguments set forward in Section 2. Hereby, we put forward some arguments which bring us to believe that risk of not comparing like with like is low. First, as argued by Davies (1996) and Nightingale et al. (2003), the major breakthrough innovation which contributed to radically change the telecommunication sector took place since the 1960s and mainly before the 2007-15 period that we analyse. During this period, firms had a similar structure and most of the telecom companies purchased the major innovations developed by the communication equipment manufacturing sectors, independently on their ownership nature.

Second, we have investigated the technological content of the patents applied for by the companies in our sample to check whether the technological development of their patenting activity can reassure us that telecom firms are contributing with relevant innovation in the telecom domain. 


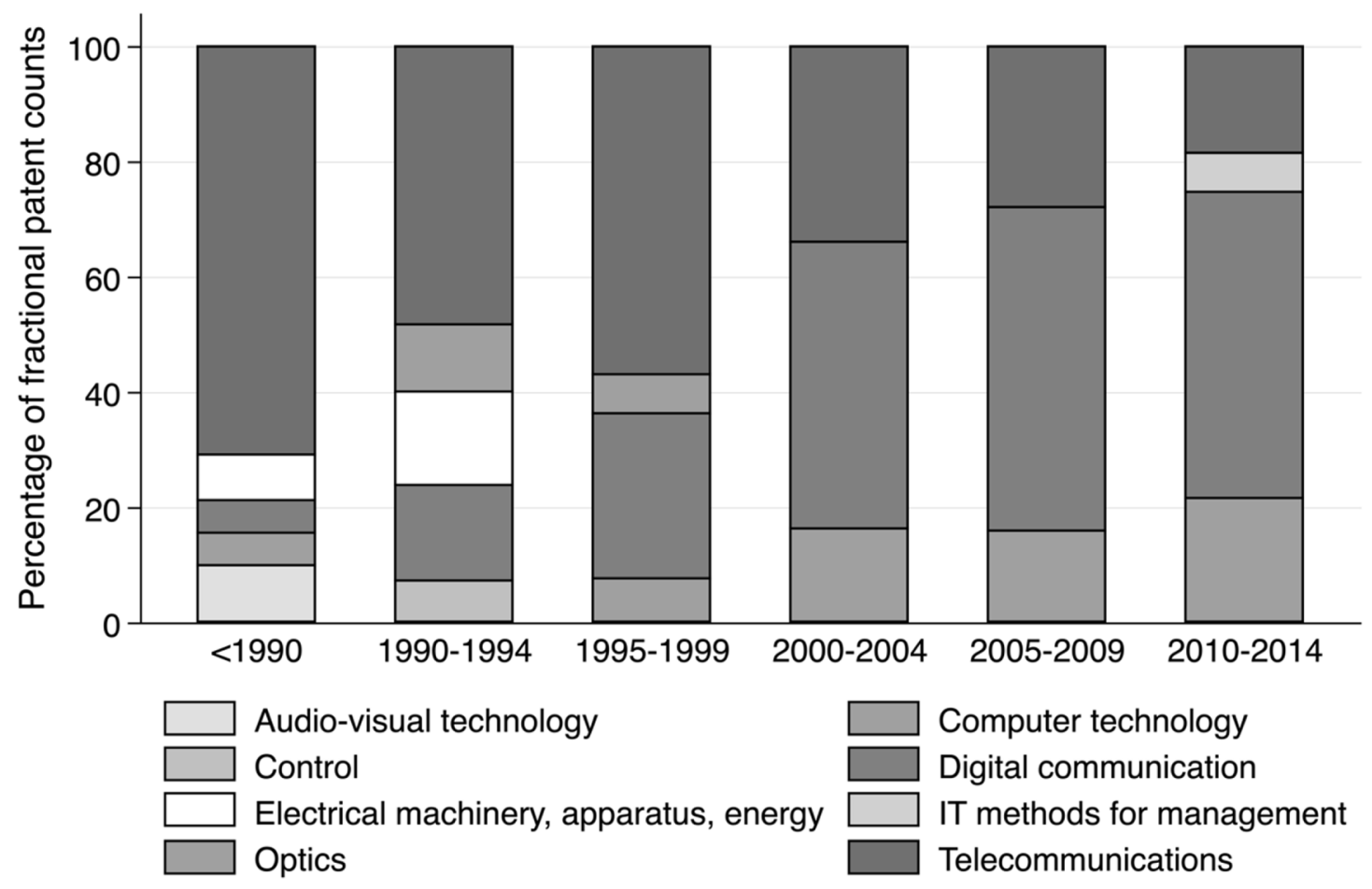

Source: Own elaboration on PATSTAT data

Fig. A1. Distribution of patents by technological categories. Source: Own elaboration on PATSTAT data.

We have retrieved information on the patents filed by the telecommunication companies in our sample from PATSTAT. PATSTAT is a comprehensive database containing patent-level information from a large number of patent offices worldwide. Notably, we collected information on the technological classes (according to the international patent classification - IPC) the patents were allocated to. As IPC technological classes are quite technical and go to a deep level of disaggregation, we resorted on aggregations of these classes in higher level constructs provided by Schmoch, 2008 and available on PATSTAT. Fig. A1 shows the relative importance of different technological fields in different time periods. While before the 1990 most of the patents filed by telecommunication companies fell inside the 'telecommunication' technological field, after the 2000 the share of patents in the 'digital communication' technological field gained prominence. This is very much in line with the technological development of innovation in the telecommunication sector following breakthrough innovation in the digital domain (Davies, 1996; Nightingale et al., 2003). At the same time, as reported by Schmoch, 2008, p. 8 of the annex) 'digital communication' is a self-contained technological field at the border between telecommunications and computer technology. It seems that, following the digital revolution, telecommunication companies increasingly focused on patenting technologies in an area combining both digital and telecommunication technologies and did not completely externalised the innovation activity to equipment and component manufacturers. Thus, we trust that the above evidence provides further support for our argument that patents are still a reliable proxy of the innovation activity carried out in the telecommunication sector and that patent data mimics well the changes which happened in the sector through time.

Third, to understand whether our analysis might be affected by a different R\&D outsourcing strategy among private and public enterprises, we further analyse the trend of their patent activity, R\&D expenditures and the cost of goods sold. If the decision to maintain internal R\&D division or to outsource it significantly changed among private and public companies, then this should result in a discontinuity in the trend of the input and output of their innovative process. Notably, if the strategy to unbundle and outsource R\&D activities prevailed among private companies compared to public ones, then this should result in a discontinuous reduction in their amount of patents, in a reduction in their R\&D expenses and in an increase in their costs compared to the SIEs, as goods that were previously developed internally are now purchased in the market. ${ }^{25}$ Fig. A2 does not show any significant discontinuity and bring us to prudentially reject the possibility that differences in the public and private patenting activity was driven by significant difference in their outsourcing strategies.

Finally, we recall that in our empirical strategy we analyse unconsolidated data and we control for the firm specific economic sector (NACE four digit). This allows us to partially account for potential differences among enterprises in their corporate structure.

Although the arguments reported above support the choice of our patent measure to proxy for innovation, we are unable to completely rule out the possibility of a bias in our results or their partial misinterpretation. As mentioned at the beginning of this section, using patents to measure innovation in an industry such as telecommunication which has been subject to a high degree of turbulence in the past decades (i.e. change in the locus of innovation, reconfiguration of firms' corporate structures, waves of liberalisations) may be problematic. For this reason, we invite the readers to interpret our results with caution and to take into consideration the arguments put forward in this section.

\footnotetext{
${ }^{25}$ Unfortunately, data on R\&D expenses, material costs and costs of goods sold are available to us only for the period 2007-15 and contain several missing observations (observations are reduced to 1342 for R\&D expenses, 1209 for the cost of goods sold and 2893 for material costs). On the contrary, patent data are available for the longer period 1985-2015 and do not present missing observations.
} 


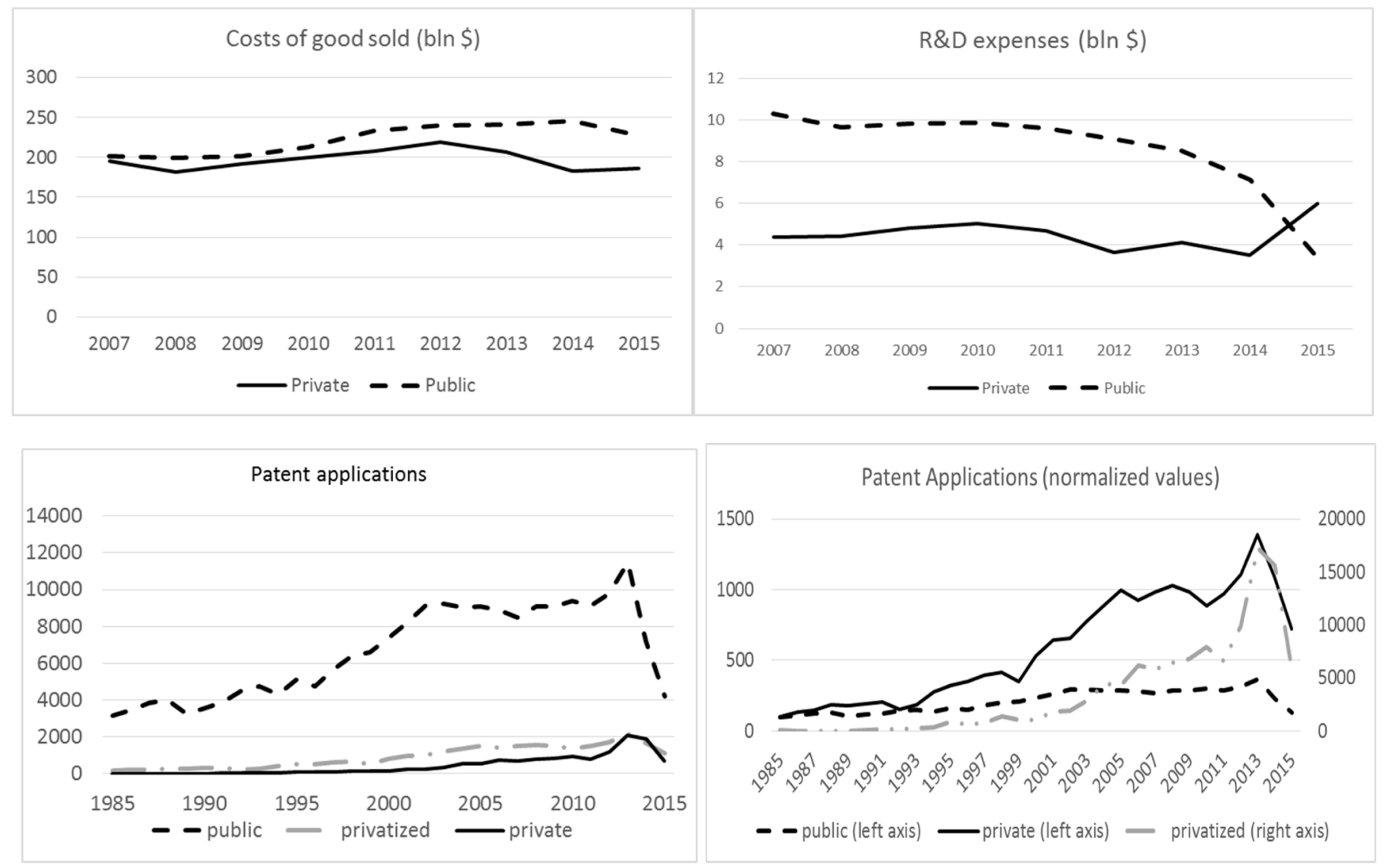

Fig. A2. Trend of cost of goods sold, R\&D and patent applications. Note - right panel: patents are normalized to 100 in the first year. Patent applications by privatized firms are reported in the right y-axis as their level was very low in 1985 when privatization was still embryonal and they experienced and exponential growth.

\section{References}

Acemoglu, D., Johnson, S., Robinson, J.A., 2001. The colonial origins of comparative development: an empirical investigation. Am. Econ. Rev. 91, 1369-1401.

Aghion, P., Bloom, N., Blundell, R., Griffith, R., Howitt, P., 2005. Competition and innovation: an inverted-U relationship. Q. J. Econ. 120 (2), 701-728.

Aghion, P., Howitt, P., 1992. A model of growth through creative destruction. Econometrica 60 (2), 323-351.

Aghion, P., Van Reenen, J., Zingales, L., 2013. Innovation and institutional ownership. Am. Econ. Rev. 103 (1), 277-304.

Andries, P., Faems, D., 2013. Patenting activities and firm performance: does firm size matter? J. Prod. Innov. Manag. 30 (6), 1089-1098.

Archibugi, T.D., Michie, J. (Eds.), 1998. Trade, growth and technical change. Cambridge University Press.

Archibugi, D., Pianta, M., 1996. Measuring technological change through patents and innovation surveys. Technovation 16 (9), 451-519.

Arrow, K., 1962. The economic implications of learning by doing. Rev. Econ. Stud. 29 (3), 155-173.

Atkinson, A.B., Stiglitz, J., 1980. Lectures in Public Economics. McGraw-Hill, London.

Baumol, W.J., 1990. Entrepreneurship: productive, unproductive and destructive. J. Polit. Econ. 98 (5), 893-921.

Busom, I., 2000. An empirical evaluation of the effects of R\&D subsidies. Econ. Innov. New Technol. 9 (2), 118-148.

Bekkers, R., Duysters, G., Verspagen, B., 2002. Intellectual property rights, strategic technology agreements and market structure: the case of GSM. Res. Policy 31 (7), 1141-1161.

Belloc, F., 2014. Innovation in state-owned enterprises: reconsidering the conventional wisdom. J. Econ. Issues 48 (3).

Bergman, E.M., 1990. The economic impact of industry-funded university R\&D. Res. Policy 19, 340-355.

Bertanha, M., Moser, P., 2016. Spatial errors in count data regressions. Journal of Econometric Methods 5 (1), 49-69.

Bertoni, F., Tykvová, T., 2015. Does governmental venture capital spur invention and innovation? Evidence from young European biotech companies. Research Policy 44 (4), 925-935.

Blundell, R., Griffith, R., Windmeijer, F., 2002. Individual effects and dynamics in count data models. J. Econom. 108 (1), 113-131.

Boeing, P., Mueller, E., 2016. Measuring patent quality in cross-country comparison.
Econ. Lett. 149, 145-147.

Borghi, E., Del Bo, C., Florio, M., 2016. Institutions and firms' productivity: evidence from electricity distribution in the EU. Oxf. Bull. Econ. Stat. 78 (2), 170-196.

Boschma, R., Capone, G., 2015. Institutions and diversification: related versus unrelated diversification in a "varieties of capitalism" framework. Res. Policy 44, 1902-1914.

Bortolotti, B., Faccio, A., 2009. Government control of privatized firms. Rev. Financ. Stud. 22 (8), 2907-2939.

Brander, J.A., Du, Q., Hellmann, T., 2015. The effects of government-sponsored venture capital: international evidence. Review of Finance 19 (2), 571-618.

Breschi, S., Malerba, F., Orsenigo, L., 2000. Technological regimes and schumpeterian patterns of innovation. Econ. J. 110 (463), 388-410.

Bushee, B.J., 1998. The influence of institutional investors on myopic R \& D investment behavior. Acc. Rev. 73 (3), 305-333.

Bushee, B.J., 2001. Do institutional investors prefer near-term earnings over long-run value? Contemp. Account. Res. 18 (2), 207-246.

Calderini, M., Scellato, G., 2005. Academic research, technological specialization and the innovation performance in European regions: an empirical analysis in the wireless sector. Ind. Corp. Change 14 (2), 279-305.

Cameron, A.C., Trivedi, P.K., 2005. Microeconometrics: Methods and Applications. university press, Cambridge.

Castelnovo, P., Del Bo, C., Florio, M., 2019. Quality of institutions and productivity of State-Invested Enterprises: International evidence from major telecom companies. European Journal of Political Economy 58, 102-117.

Castelnovo, P., Florio, M., Forte, S., Rossi, L., Sirtori, M., 2018. The economic impact of technological procurement for large-scale research infrastructures: evidence from the large hadron collider at Cern. Res. Policy 47 (9), 1853-1867.

Choi, S.B., Lee, S.H., Williams, C., 2011. Ownership and firm innovation in a transition economy: evidence from China. Res. Policy 40 (3), 441-452.

Choi, S.B., Park, B., Hong, P., 2012. Does ownership structure matter for firm technological innovation performance? The case of Korean firms. Corp. Govern. 20 (3).

Christiansen, H., Kim, Y., 2014. State-Invested Enterprises in the Global Marketplace: Implications for a Level Playing Field. OECD Publishing OECD Corporate Governance Working Papers, No. 14.

Clifton, J., Comín, F., Díaz-Fuentes, D., 2011. From national monopoly to multinational corporation: how regulation shaped the road towards telecommunications inter nationalization. Bus. Hist. 535, 761-781.

Commander, S., Svejnar, J., 2011. Business environment, exports, ownership, and firm performance. Rev. Econ. Stat. 93, 309-337.

Davies, A., 1996. Innovation in large technical systems: the case of telecommunications. 
Ind. Corp. Change 5 (4), 1143-1180.

Delbono, F., Denicolo, V., 1993. Regulating innovative activity: the role of a public firm. Int. J. Ind. Organ. 11 (1), 35-48.

Demircioglu, M.A., Audretsch, D.B., 2017. Conditions for innovation in public sector organizations. Res. Policy 46 (9), 1681-1691.

Dewenter, K., Malatesta, P., 2001. State-owned and privately owned firms: an empirical analysis of profitability, leverage, and labor intensity. Am. Econ. Rev. 91 (Mar(1)), 320-334 v.

Dollar, D., Hallward-Driemeier, M., Mengistae, T., 2005. Investment climate and firm performance in developing economies. Econ. Dev. Cult. Change 54, 1-31.

European Commission, 2016. State-Owned Enterprises in the EU: Lessons Learnt and Ways Forward in a Post-Crisis Context. Institutional paper 31. https://ec.europa.eu/ info/publications/economy-finance/state-owned-enterprises-eu-lessons-learnt-andways-forward-post-crisis-context_en.

Faccio, M, Zingales, L, 2017. Political determinants of competition in the mobile telecommunication industry. NBER Working Paper 23041.

Fang, L., Lerner, J., Wu, C., 2016. Intellectual Property Rights Protection, Ownership, and Innovation: Evidence from China. NBER Working Paper No. 22685.

Ferreira, D., Manso, G., Silva, A.C., 2013. Incentives to innovate and the decision to go public or private. Rev. Financ. Stud. 27 (1), 256-300.

Finger, M., Kunneke, R.W. (Eds.), 2011. International Handbook of Network Industries: The Liberalization of Infrastructure. Edward Elgar Publishing.

Florio, M., 2004. The great divestiture: Evaluating the welfare impact of the British privatizations, 1979-1997. MIT press.

Florio, M., 2013. Network Industries and Social Welfare: The Experiment that Reshuffled European Utilities. OUP, Oxford.

Florio, M., Giffoni, F., Giunta, A., Sirtori, E., 2018. Big science, learning, and innovation: evidence from Cern procurement. Ind. Corp. Change 27 (5), 915-936.

Foray, D., 2004. The Economics of Knowledge. MIT Press.

Francis, J., Smith, A., 1995. Agency costs and innovation: some empirical evidence. J. Account. Econ. 19 (2-3), 383-409.

Gil-Moltó, M.J., Poyago-Theotoky, J., Zikos, V., 2011. R\&D subsidies, spillovers, and privatization in mixed markets. South. Econ. J. 78 (1), 233-255.

Fransman, M., 1994. AT\&T, BT and NTT: The role of R\&D. Telecommunications Policy 18 (4), 295-305.

Freeman, C., Soete, L., 1997. The Economics of Industrial Innovation. The MIT Press.

Gil-Moltó, M.J., Poyago-Theotoky, J., Rodrigues-Neto, J.A., Zikos, V., 2019. Mixed oligopoly, cost-reducing research and development, and privatisation. Eur. J. Oper. Res. https://doi.org/10.1016/j.ejor.2019.11.071.

Godoe, H., 2000. Innovation regimes, R\&D and radical innovations in telecommunications. Res. Policy 29 (9), 1033-1046.

Gourieroux, C., Monfort, A., Trognon, A., 1984. 'Pseudo maximum likelihood methods: applications to Poisson models. Econometrica: Journal of the Econometric Society 52 (3), 701-720.

Gradstein, M., 2004. Governance and growth. J. Dev. Econ. 73, 505-518.

Griliches, Z., 1990. Patent statistics as economic indicators: a survey. J. Econ. Lit. 28 (4), 1661-1707.

Griliches, Z., 1979. Issues in assessing the contribution of research and development to productivity growth. Bell J. Econ. 10 (1), 92-116.

Griliches, Z., 2007. R\&D and productivity: The econometric evidence. University of Chicago Press.

Grossman, G.M., Helpman, E., 1991. Trade, knowledge spillovers, and growth. Eur. Econ. Rev. 35, 517-526.

Guerzoni, M., Raiteri, E., 2015. Demand-side vs. supply-side technology policies: hidden treatment and new empirical evidence on the policy mix. Res. Policy 44 (3), 726-747.

Hagedoorn, J., Cloodt, M., 2003. Measuring innovative performance: is there an advantage in using multiple indicators? Res. Policy 32 (8), 1365-1379.

Helpman, E., 2004. The Mystery of Economic Growth. Harvard University Press, Cambridge, MA.

Hipp, C., Grupp, H., 2005. Innovation in the service sector: the demand for service-specific innovation measurement concepts and typologies. Res. Policy 34 (4), 517-535.

Holmstrom, B., 1999. Managerial incentive problems: a dynamic perspective. Rev. Econ. Stud. 66 (1), 169-182.

Holmstrom, B., Milgrom, P., 1991. Multitask principal-agent analyses: incentive contracts, asset ownership, and job design. J. Law Econ. Organ. 7, 24-52.

Hu, A.G., Jefferson, G.H., 2009. A great wall of patents: what is behind China's recent patent explosion? J. Dev. Econ 90 (1), 57-68.

Jamasb, T., Pollitt, M.G., 2011. Electricity sector liberalisation and innovation: an analysis of the UK's patenting activities. Res. Policy 40 (2), 309-324.

Kaldor, N., 1980. Public or private enterprise - the Issue to be considered. In: Baumol, W.J. (Ed.), Public and Private Enterprises in a Mixed Economy. St. Martin's, New York, pp. 1-12.

Kaplan, S.N., Minton, B.A., 2012. How has ceo turnover changed? Increasingly performance sensitive boards and increasingly uneasy CEOs. Int. Rev. Finance 12, 57-87.

Kaufmann, D, Kraay, A, Mastruzzi, M, 2007. Worldwide Governance Indicators Project: Answering the Critics. World Bank Policy Research Working Paper 41049.

Kaufmann, D., Kraay, A., Mastruzzi, M., 2011. The worldwide governance indicators: methodology and analytical issues. Hague J. Rule Law 3 (2), 220-246.

Kaufmann, D., Kraay, A., 2008. Governance indicators: where are we, where should we be going? World Bank Res. Obs. 23, 1-30.

Khandelwal, A., Schott, P., Wei, S., 2013. Trade liberalization and embedded institutional reform: evidence from Chinese exporters. Am. Econ. Rev. 1036, 2169-2195.

Kleinknecht, A., Van Montfort, K., Brouwer, E., 2002. The non-trivial choice between innovation indicators. Econ. Innov. New Technol. 11 (2), 109-121.

Knack, S., 2006. Measuring corruption in Eastern Europe and Central Asia: a critique of the cross-country indicators. The World Bank 3698.
Koske, I., Wanner, I., Bitetti, R., Barbiero, O., 2015. The 2013 Update of the OECD's Database on Product Market Regulation: Policy Insights for OECD and Non-OECD Countries. OECD Publishing, Paris OECD Economics Department Working Papers, No. 1200.

Kurtz, M.J., Schrank, A., 2007. Growth and governance: Models, measures, and mechanisms. The Journal of Politics 69 (2), 538-554.

La Porta, R, Lopez de Silanes, F, Shleifer, A, Vishny, R, 1998. Law and finance. Journal of political economy 106 (6), 1113-1155.

Laffont, J.J., Tirole, J., 1993. A Theory of Incentives in Procurement and Regulation. MIT Press, Cambridge, Mass.

Lam, P.L., Shiu, A., 2010. Economic growth, telecommunications development and productivity growth of the telecommunications sector: evidence around the world. Telecommun. Policy 34 (4), 185-199.

Lanjouw, J.O., Schankerman, M., 2004. Patent quality and research productivity: measuring innovation with multiple indicators. Econ. J. 114 (495), 441-465.

Lazzarini, S., Mesquita, L.F., Monteiro, F., Musacchio, A., 2016. Leviathan as an inventor: patenting intensity, originality, and impact of state-owned MNC firms. Academy of Management Annual Meeting Proceedings.

Leoncini, R., Marzucchi, A., Montresor, S., Rentocchini, F., Rizzo, U., 2019. 'Better late than never': the interplay between green technology and age for firm growth. Small Bus. Econ. 52, 891-904. https://doi.org/10.1007/s11187-017-9939-6.

Long, W., Ravenscraft, D., 1993. LBOs, debt and R\&D intensity. Strategic Manag. J. 4, 119-135.

Malerba, F., Orsenigo, L., 1994. Schumpeterian patterns of innovation. Cambr. J. Econ. 19 (1), 47-66.

Malerba, F., Orsenigo, L., 1996. Schumpeterian patterns of innovation are technology specific. Res. Policy 25 (3), 451-478.

Mansfield, E., 1991. Academic research and industrial innovation. Res. Policy 20, 1-12.

Mansfield, E., 1998. Academic research and industrial innovation: an update of empirical findings. Res. Policy 26, 773-776.

Marin, G., 2014. Do eco-innovations harm productivity growth through crowding out? Results of an extended CDM model for Italy. Res. Policy 43 (2), 301-317.

Mauro, P., 1995. Corruption and growth. Q. J. Econ. 110 (3), 681-712.

Mazzucato, M., 2013. The Entrepreneurial State - Debunking Public vs. Private Sector Myths. Anthem Press ISBN 978-0-857282-52-1.

Mazzucato, M., 2016. From market fixing to market-creating: a new framework for innovation policy. Ind. Innov. 23 (2), 140-156.

Mazzucato, M., 2017. Mission-Oriented Innovation Policy: Challenges and Opportunities. UCL Institute for Innovation and Public Purpose Working Paper, (2017-1).

Mazzucato, M., 2018. Mission-oriented research \& innovation in the European Union. A Problem-Solving Approach to Fuel Innovation-Led Growth. European Commission, Directorate-General for Research and Innovation.

Megginson, W.L., Netter, J.M., 2001. From state to market: a survey of empirical studies of privatization. J. Econ. Lit. 39, 321-389.

Millward, R., 2005. Private and Public Enterprise in Europe: Energy, Telecommunications and Transport. Cambridge University Press, pp. 1830-1990.

Millward, R., 2011. The institutional economic history of infrastructure industries c. 1830-1990: ideology, technology, geo-politics. In: Finger, M., Künneke, RW (Eds.), International handbook of Network Industries. The liberalization of Infrastructure. Edward Elgar, Cheltenham, UK, pp. 87-99.

Munari, F., Oriani, R., 2005. Privatization and economic returns to R\&D. Ind. Corp. Change 14 (1), 61-91.

Musacchio, A., Lazzarini, S., 2018. State ownership reinvented? Explaining performance differences between state-owned and private firms. Corp. Govern forthcoming.

Nambisan, S., 2013. Industry technical committees, technological distance, and innovation performance. Res. Policy 42 (4), 928-940.

Nelson, R.R. (Ed.), 2005. The limits of market organization. Russell Sage Foundation.

Nightingale, P., Brady, T., Davies, A., Hall, J., 2003. Capacity utilization revisited: software, control and the growth of large technical systems. Ind. Corp. Change 12 (3), 477-517.

North, D.C., 1990. Institutions, Institutional Change and Economic Performance. University Press, New York, Cambridge.

Obinger, H., Schmitt, C., Traub, S., 2016. The political economy of privatization in rich democracies. Oxford University Press.

OECD, 2015. OECD Guidelines on Corporate Governance of State-Owned Enterprises. OECD Publishing.

Pargendler, M., Musacchio, A., Lazzarini, S., 2013. In strange company: the puzzle of private investment in state-controlled firms. Cornell. Int. Law J. 46, 569.

Porter, M., 1992. Capital disadvantage: America's failing capital investment system. Harvard Bus. Rev. 65-83.

PWC, 2015. State-Owned Enterprises Catalysts for public value creation? Price Waterhouse Cooper Publishing. https://www.pwc.com/gr/en/publications/assets/ state-owned-enterprises-catalysts-for-public-value-creation.pdf.

Rajan, R., Zingales, L., 1998. Financial dependence and growth. Am. Econ. Rev. 88, 559-586.

Rigobon, R., Rodrik, D., 2004. Rule of Law, Democracy, Openness, and Income: Estimating the Interrelationships. NBER Working Paper No. 10750.

Rodriguez-Pose, A., Di Cataldo, M., 2015. Quality of government and innovative performance in the regions of Europe. J. Econ. Geogr. 15, 673-706.

Romer, P.M., 1986. Increasing returns and long-run growth. J. Polit. Econ. 94 (5), 1002-1037.

Romer, P.M., 1990. Endogenous technological change. J. Polit. Econ. 98 (5), S71-S102.

Rong, Z., Wu, X., Boeing, P., 2017. The effect of institutional ownership on firm innovation: evidence from, Chinese listed firms. Res. Policy 46 (9), 1533-1551.

Sala-i-Martin, X., 2002. 15 Years of New Growth Economics: What Have we Learnt? Central Bank of Chile Working Paper 172. 
Salter, A.J., Martin, B., 2001. The economic benefits of publicly funded basic research: a critical review. Res. Policy 30 (3), 509-532.

Sapra, H., Subramanian, A., Subramanian, K., 2013. Corporate governance and innovation: theory and evidence. J. Financ. Quant. Anal. 49 (4), 957-1003.

Schmoch, U, 2008. Concept of a technology classification for country comparisons. Final Report to the World Intellectual Property Organisation (WIPO). http://www.worldintellectual-property-organization.com/edocs/mdocs/classifications/en/ipc_ce_41/ ipc_ce_41_5-annex1.pdf, Accessed date: 3 September 2019.

Segarra-Blasco, A., Arauzo-Carod, J.M., 2008. Sources of innovation and industry-university interaction: evidence from Spanish firms. Res. Policy 37, $1283-1295$.

Shleifer, A., 1998. State versus private ownership. J. Econ. Perspect. 12 (4), 133-150. Shleifer, A., Vishny, R.W., 1994. Politicians and firms. Q. J. Econ. 109, 995-1025.

Stein, J.C., 1988. Takeover threats and managerial myopia. J. Polit. Econ. 96 (1), 61-80.

Squicciarini, M., Dernis, H., Criscuolo, C., 2013. Measuring Patent Quality. OECD Working Paper.

Sterlacchini, A., 2012. Energy R\&D in private and state-owned utilities: an analysis of the major world electric companies. Energy Policy 41, 494-506 February 2012.

Szarzec, K., Nowara, W., 2017. The economic performance of state-owned enterprises in Central and Eastern Europe. Post-Commun. Econ. 29 (3), 375-391.

Tebaldi, E., Elmslie, B., 2008. Institutions, innovation and economic growth. J. Econ. Dev. 33 (2), 1-27.

Tebaldi, E., Elmslie, B., 2013. Does institutional quality impact innovation? Evidence from cross-country patent grant data. Appl. Econ. 45 (7), 2013.

Thoma, G, Torrisi, S, Gambardella, A, Guellec, D, Hall, B, Harhoff, D, 2010. Harmonizing and combining large datasets-An application to firm-level patent and accounting data. NBER working paper series 15851.
Thornhill, S., 2006. Knowledge, innovation and firm performance in high-and low-technology regimes. J. Bus. Vent. 21 (5), 687-703.

Trajtenberg, M., 2002. Government support for commercial R\&D: lessons from the Israeli experience. In: Adam, B.J., Josh, L., Scott, S. (Eds.), Innovation Policy and the Economy 2. pp. 79-134 Available at: URL: http://www.nber.org/chapters/c10786.

United Nations Secretary-General, 2004. Report of the Secretary-General on the Rule of Law and Transitional Justice in Conflict and Post-Conflict Societies (S/2004/616).

Ure, J., 2003. Telecommunications privatization: Evidence and some lessons. Telecommunications Research Project Papers 2. Academic Version, pp. 11.

Veugelers, R., Cassiman, B., 2005. R\&D cooperation between firms and universities. Some empirical evidence from Belgian manufacturing. Int. J. Ind. Organ. 23, 355-379.

Vining, A.R., Boardman, A.E., 1992. Ownership versus competition: efficiency in public enterprise. Public Choice 73 (2), 205-239.

Vickers, J., Yarrow, G., 1991. Economic perspectives on privatization. J. Econ. Perspect. 5 (2), 111-132.

Williams, A., Siddique, A., 2008. The use (and abuse) of governance indicators in economics: a review. Economics of Governance 9 (2), 131-175.

Williamson, O.E., 1985. The Economic Institutions of Capitalism. Macmillan, New York. Wonglimpiyarat, J., 2006. The dynamic economic engine at Silicon Valley and US Government programmes in financing innovations. Technovation 26, 1081-1089.

Wooldridge, J.M., 1999. Distribution-free estimation of some nonlinear panel data models. Journal of Econometrics 90 (1), 77-97.

Xie, C., 2012. How does privatization affect innovation? An integrative model. J. Strategic Innov. Sustain. 8 (2).

Zahra, S.A., Fescina, M., 1991. Will leveraged buyouts kill U.S. corporate research and development? Acad. Manag. Exec. 5, 7-21. 